\title{
Checklist of plants in the University Botanic Garden of Maseno and their significances to the society
}

\author{
Stephen F. Sikolia ${ }^{1}$ and Seline Omondi ${ }^{1}$ \\ Department of Botany, Maseno University, Kenya
}

\begin{abstract}
A botanical garden is an area set aside and maintained by an organization for growing and studying various groups of plants for aesthetic, conservation, economic, educational, recreational and scientific purposes. A lot of research on checklisting of vascular plants has been or is being carried out in various botanic gardens around the world. At the University Botanic Garden Maseno, no elaborate research on check listing of plant species has been done. There has scarcely been any attempt to carry out phytochemical analysis on various in situ and ex situ plants conserved at the University Botanic Garden and no research has been done to document the educational and economic values of the garden. Moreover, the rate at which the plant biodiversity is being cleared is alarming, and calls for urgent need of conserving plants of high economic values. It is on the basis of such need that the study was carried out at the University Botanic Garden, Maseno (UBGM). The study was carried out over a period of eleven months. The main objective of the study was to identify and provide checklist of plants conserved at the University Botanic Garden, Maseno. During field survey observations were made, interviews conducted and notes taken on plant morphological characteristics and habit of plants. Some plants were identified through the available literature, and by the aid of the herbarium specimens in the University botanic garden. Unidentified plants were collected, pressed, dried, preserved, mounted and identified at the National museums of Kenya herbarium. Voucher specimens of the same were deposited in the University botanic garden herbarium. It was found that there are 235 plant species in the botanic garden, belonging to 66 families. For each plant species, species name, author name(s), common name (where available), family, habit and use of plant species were provided. A plant usage was considered valid when cited by three different respondents. Interviews based on the questionnaire were administered to members of the surrounding community and workers in the garden. The questionnaires were also issued to the botany students and staff of the University. Through it, economic and educational values of the University botanic garden and conservation strategies of threatened plants ex situ in the garden were gathered. The data collected was presented using tables and pie-charts, and then analysed using SPSS programme. The data collected was presented using tables. The information collected through annotated checklist will be used to provide database of vascular plants of high economic value found within the University Botanic Garden, provide information on phytochemicals present in some medicinal plants and hence need for sustainable biodiversity conservation. The knowledge of such medicinal plants will provide vital information to the local community members who still rely on herbal medicine for the treatment of most diseases.
\end{abstract}

(Keywords: Checklist of plants, University Botanic Garden of Maseno (UBGM), Uses of plants)

\section{Introduction}

The University Botanic Garden, Maseno (UBGM) is found within Maseno University, which is located in the Lake Victoria basin within Western Kenya (Onyango and Onyango, 2005) [1]. The UBGM has a rich floral diversity which has been conserved in situ as well as ex situ. Botanic gardens are as old as history itself. According to Wikipedia encyclopedia (2011a) [2], botanic gardens are generally well-tended parks displaying a wide range of plants labeled with their botanical name. A botanic garden is also defined as an institution for advancement and diffusion of botanical knowledge and a love of plants (Swaminathan and Kochhar, 1989) [3]. According to Botanic Garden Conservation International (BGCI) (2011a) [4], a botanic garden is an institution that is open to the public, has a reasonable degree of permanence, and is undertaking scientific or technical research on plants in the collections, has adequate labeling of the plants and proper documentation of the collections, including wild origin. Botanic gardens have in the past, and continue today to play major roles and purposes in society and world cultures [3] [4]. According to the International Agenda for Botanic Garden Conservation [4], botanic gardens play important roles as the world's greatest resource for cultivation and conservation of individual plant species. Their actions should be directed towards promoting integrated biodiversity conservation (combining and utilizing ex situ and in situ techniques). Biodiversity is most often defined as the totality of genes, species and ecosystems of a region (Frankel, Brown and Burdon, 1995) [5].

Biodiversity is the full complexity and variety of life, at all scales, from genetic diversity, up to species and even ecosystem levels [4]. Biodiversity has become a topic of debates, discussions and deliberations since the Rio and Durban biodiversity conventions on sustainable utilization of biodiversity [1]. These Conventions on 
Biological Diversity (CBD) recognized the importance of life sustaining systems of the biosphere. The Rio convention reported the significances of the conservation and sustainable use of biological diversity in the basic provision for food, health and other needs of the growing world populations [4]. Biodiversity provide for the intrinsic value and its components have ecological, social economic, scientific, educational, cultural, recreational and aesthetic values (Wikipedia encyclopedia, 2011c) [6].

According to African Botanic Gardens Network (BGCI, 2011e) [7], gardens in Africa have come to realize the enormity of a varied range of environmental problems that exist in the continent and have taken up the challenge of addressing them. Lack of awareness is a major constraint in the implementation of measures to conserve biological resources [7]. It is on this basis that the research will document the economic and educational values of the UBGM with the aim of such information creating awareness among the local and international community, on the role of the garden in conservation. Other roles of botanic gardens include sustainable use of biodiversity, information exchange, training and capacity building. Research is another vital role played by botanic gardens, and which must fully be recognized [4]. The research emphasis of botanic gardens covers many areas like ecology has been done at Harvard University botanic garden (Sairers, 2010) [8]. At Beijing botanic garden, research on conservation has been done (Zhiming, 1993) [9] and at Singapore University botanic garden, research on plant taxonomy has been done (Tan, Ibrahim, Chew, Chua, Duistermaat, Lee, Leong, Loo, Lum, Suran, Wee, Yap and Yong, 2008) [10]. At the University of British Columbia botanic garden, research has been done on ecological and socioeconomic impacts on invasive alien species in island ecosystems (Reaser, Meyerson, Green, Orapa, Saunders and Shine, 2007) [11].

In Kenya, many studies on check listing have been done on various ecological regions (Kokwaro, 1982 [12]; Muasya, Young and Okebiro, 1994 [13]; Luke, 2005 [14] and Fischer, Rembold, Althof, Obholzer, Malombe, Mwachala, Onyango, Dumbo and Theisen, 2010 [15]). Elsewhere around the world, research on check listing of plants have been done or is on-going in various botanic gardens (Chong, Hugh and Corlett, 2009 [16]; Forzza, José, Carlos, Canhos, Sylvestre, Bruno, Zappi, Leitman, Lohmann, Lughadha, and Martinelli, 2010 [17]; Lechner and Kiehn, 2010 [18]). Although these studies have been done, no elaborate research on check listing of the plants has been done at the UBGM. This research endeavors to provide a checklist for in situ and ex situ plants conservation at the UBGM. The UBGM plant database is very crucial and will contribute to the improvement of research on medicinal plants (Manha, Silva, Alves, Almeida and Brandao, 2008 [19]) as well as research on other plants with different economic values. This research is geared towards the contribution of the botanic garden towards the Global Strategy for Plant Conservation [4].

Conservation of biodiversity is imperative since the biodiversity is being lost at an unprecedented rate (Heywood and Watson 1995 [20]; Jeruto, 2008 [21]). There are now many threats to the natural resources of our planet. In the neighbouring areas around the UBGM, just like in other several parts of the country, the survival of most plants in their natural setting is threatened as there is a lot of pressure on the plants due to land clearance to provide space for buildings, allied infrastructure development, agriculture, tree burning for charcoal and an unsustainable mode of harvesting medicinal plants, where roots and stem bark are the most preferred (Cunningham, 1997 [22]; UNESCO, 1997 [23]). This therefore calls for conservation strategies to be put in place to save these plants from extinction.

In 1978, WHO reported that $90 \%$ of the rural dwellers receive health care from traditional healers. It is now estimated that about $80 \%$ of the population in Africa rely on traditional medicine for primary health care (Karori and Pulu, 2003) [24]. The members of the community around the UBGM, who are mainly Luos and Luhyas are no exception (Pers.Com.). They still rely on traditional medicine for their primary health care, and during dry seasons when food scarcity is a major problem, the poor rural communities harvest wild plants, including fruits and leaves for food (Elizabetsky, 1991) [25]. Apart from food and medicine, plants also supply shelter, clothing, fuel, crafts and cosmetics to rural and urban areas. In addition, they are sources of income and employment to the rural communities who collect and sell natural herbal products to urban and rural areas (Kokwaro, 1993 [26]; Balick and Cox, 1994 [27]) [24]. Due to the significance of plants to the local community, coupled with the alarming rate at which most plant biodiversity is being threatened with extinction in the continental Africa (Scholes, Kuper and Biggs, 2007) [28], there is urgent need to devise strategies to not only save these plants from extinction but also to increase the supply of plant products as well as protect the habitat [21]. This could be achieved through enhancing modern propagation techniques, practising sustainable harvesting techniques, identifying and collecting germplasm from plants of high economic importance and preserving them as well as raising them ex situ in UBGM.

\subsection{Justification}

The study provide a database of plants found within the University Botanic Garden, Maseno and show case the need for conservation including sustainable use of plants for green environment. Documentation on the invasive plants within the garden, is provided with measures being put in place to manage them. Also, the data will enlighten the local as well as the international community on the threatened plant species that need to be 
conserved ex situ in the garden and other services provided by the garden. Further, check listing of plants in botanic gardens is a requirement by the Botanic Garden Conservation International. A lot of research on check listing of vascular plants have been or is being carried out in various botanic gardens around the world. At the University Botanic Garden Maseno however, no elaborate research on check listing of these plant species and research has been done to documentation on the educational and economic values of the garden has been done. Further, the neighbouring areas around the garden, just like in other several parts of the country, the survival of most plants in their natural setting is threatened as there is a lot of pressure on the plants due to land clearance to provide space for buildings, allied infrastructure development, agriculture and tree burning for charcoal. This therefore calls for conservation strategies to be put in place to save these plants from extinction. Therefore, there is the need to identify and provide checklist of plants conserved at the University Botanic Garden, Maseno.

\subsection{Checklist of Plants}

\section{Literature Review}

Plants are vital for the survival and well-being of other organisms. However, the survival of most plants isthreatened. According to BGCI (2011b) [29], and Rinker (2002) [30], it is estimated that there are 270,000 plant species in the world, one in eight are threatened with extinction. Humans being the main cause of extinction and the principle threat to species at risk of extinction [29].The major threats to plant diversity include, habitat loss and degradation, invasive species, over-exploitation, pollution, disease and climate change (Oldfield, 2011) [29]. According to BGCI (2011c) [31], a quarter of the 1157 species of Rhododendron plants and 78 wild oaks are in danger of extinction. This therefore calls for need of their protection through ex situ conservation.

Some of the plants at the University Botanic Garden, Maseno have medicinal values. For many centuries plant based medicaments have been man's prime weapon and still is in the frontline for treating large number of diseases [20]. In Kenya, the role of plants as sources of medicine has been recognized and as scientific knowledge on the medicinal values of indigenous plants increases (Rukangira, 2001) [32] there is a proportional increase in demand for herbal products both locally and internationally. In Traditional African societies, several medicinal plants were used to treat various diseases and conditions, for example, Prunus africanus bark (Pygeanum powder) has been used to treat prostate cancer, Rauvolfia species roots (reserpine) have been used to treat high blood pressure and Cinchona species whose active ingredient is quinine is used in the treatment of malaria [3]. Expanding herbal product market poses a risk of over harvesting of medicinal plants and this has serious implications on the survival of several plant species, and threatens biodiversity. This therefore calls for conservation of medicinal plants of high economic values in the botanic garden. Checklisting studies have been done on various ecological regions in Kenya. The documented checklist of botanical nature include, Samburu and Rendile names of plants, Marsabit district [12], Ol Ari Nyiro Ranch and Mukutan Gorge, Laikipia [13], the Shimba Hills, Kwale district [14] and vascular plants of Kakamega Forest, Western Kenya [15] have been done in Kenya.

Elsewhere around the world, research on checklist of plants in various botanic gardens has been done or is ongoing. For instance, research on world checklist of selected plant families has been done at the Royal Botanic Gardens, Kew. A checklist of the genus Quercus, which quickly grew into a checklist of the whole of Fagales was compiled by Rafaël Govaerts in 1994 (Govaerts, 1994) [33]. Because of its usefulness, a program was initiated to compile global checklists of plant families of particular interest, and the families selected were mainly those that were a research focus for Kew. In 2001, the focus became concentrated on compiling all Monocotyledon families, which was completed in 2006. The program then focused on contributing to a working list of known seed plants as set out by the CBD as their Target one. This process is ongoing and further contributions facilitated [33]. The main goal of the checklists is to provide high quality baseline data on all accepted taxa included in each family. The main focus being the name as this is the single most important element necessary to communicate about plants and the key to biodiversity. At the Singapore University botanic garden, research on checklist of the total plant flora of Singapore and checklist of threatened species of seed plants in Singapore has been done [10] [16]. At the Rio de Janeiro botanic garden, research on the preparation of a list of Brazilian plant and fungal species has been done [17]. At UBGM however, no research on check listing of the vascular plant species has been done. Check listing will provide a database of all vascular plants present at the UBGM and therefore assist in their conservation and sustainability as well as expand the documented knowledge of the UBGM flora.

\subsection{Invasive Plants}

According to Richardson, Pysek, Rejmánek, Barbour, Panetta and West (2000) [34], invasive species are exotic species that overcome successive barriers limiting their reproduction, naturalization or dispersal, allowing them to spread in their new area of introduction. However, the term itself of invasive species is confusing: a species can never be invasive in and of itself; only a population of a species can be invasive, in a 
given place and at a given time (Colautti and MacIsaac, 2004) [35].The term aside, examples of invasive plants are the purplewitchweed (Striga hermonthica), Andean Pampas grass (Cortaderia jubata), water hyacinth (Eichornia crassipes), and Tropical Soda Apple (Solanum viarum). These invasive alien species (IAS) can cause great economic health and ecological problems all around the globe [18] for example the Water hyacinth in Kenya. According to Kramer and Hird (2011) [36], invasive plants, pests and pathogens are among the greatest threats to biodiversity and they pose a significant threat to global economic health with estimated costs of US $\$ 350$ billion annually. The management of the invasive plants is significant step for plant conservation around the world and their removal crucial for the conservation of threatened plants [31] and more broadly for ecological restoration. Botanic gardens play an important leadership role in protecting the world's plant biodiversity, minimizing the impact of invasive species [4].

\subsection{Conditions that lead to Invasion}

According to Heywood and Brunel (2009) [37], it is widely recognized that ornamental horticulture has been the main pathway of plant invasions and that most invasive plants have been introduced by nurseries and botanic gardens or by individuals (Reichard and White, 2001) [38]. Botanic gardens, especially those located in tropical countries, have often been implicated as the source of such invasions (Dawson, Mndolwa, Burslem and Hulme, 2008 [39]; Hulme, 2011 [40) although it is not always easy to establish the full facts (Galera and Sudnik, 2010) [41]. Given that IAS are widely regarded as one of the main threats to biodiversity today, it is imperative for botanic gardens to consider what actions they can take to prevent such invasions or to deal with existing ones.According to Groom (2011) [42], botanic gardens need to be constantly alert to the possibility of introducing new invasive species. Even botanic gardens with a high awareness of the problem may have conditions that make them prone to losing control of the plants they grow. Many of mankind's activities can result in invasive plants, yet there are good ecological and evolutionary reasons why botanic gardens are particularly liable to causing new invasions. According to Facon, Genton, Shykoff, Jarne, Estoup and David, (2006) [43], there are three basic scenarios of plant invasions; migration change, environmental change and evolutionary change. In migration it is worthy to note that the range of some species is only restricted by their ability to disperse. Such species will survive in new areas, but they are unable to reach such areas by natural spread (Sax and Brown, 2000) [44]. Botanic gardens are skilful at growing introduced species, some of which have the ability to grow and reproduce more rapidly than native species. Common invasive species traits include their ability to reproduce both asexually and sexually, fast growth, rapid reproduction, high dispersal ability, phenotypic plasticity (the ability to alter one's growth form to suit current conditions), tolerance of a wide range of environmental conditions and their ability to live off of a wide range of food types (Wikipedia encyclopedia, 2011b) [45]. One of the reasons for the success of invasive plants is that they are released from the stress of pests and diseases that occur in their native ranges (Keane and Crawley, 2002) [46].Studies indicate AShas fewer pests and diseases in their invasive ranges [42].

Environment is another condition that may lead to invasiveness. A large number of invasive species occurring places disturbed by human activity,such as in urban environments, on agricultural land and by roadsides(Lozon and MacIsaac, 1997) [47]. This may, in part, be explained by the creation of novel habitats. The proximity of botanic gardens to large urban areas, full of novel, unexploited habitats, certainly raises the risk of new invasions being initiated by garden escapes. Further, the influences of botanic gardens, novel habitats, disturbance and horticultural novelty are key to the introduction histories of many species [40].Evolutionary change also plays important role in plant invasiveness. It has been argued that a species, when liberated from the competition,environmental stress and pests and diseases of its native habitats, can evolve to reallocate its resources from protective mechanisms into traits which confer greater invasive potential (Blosseyand Notzold, 1995) [48]. While such evolution is generally suggested to occur in wild populations there is certainly also unconscious selection occurring in botanic gardens (Matthiesa,Enßlin and Sandnera, 2011) [49]. It is likely that unconscious selection for improved survival in a garden may also means election for traits that encourageweediness. Hybridisation has been implicated in the evolution of invasive plants (Ellstrand and Schierenbeck, 2000) [50]. Examples areCasuarina ssp. in Florida (Gaskin, Wheeler, Purcell and Taylor, 2009) [51] and Fallopia ssp. in Belgium (Tiébré, Vanderhoeven, Saad and Mahy, 2011) [52].

Checklisting of invasive plants have been done in various parts around the world. For example, preliminary check-list of invasive alien plant species in Croatia have been done (Bor $\AA_{j} i \mathrm{Ä}_{\ddagger}^{\ddagger}$, Milovi $\ddot{A ̈}_{\ddagger}^{+}$,

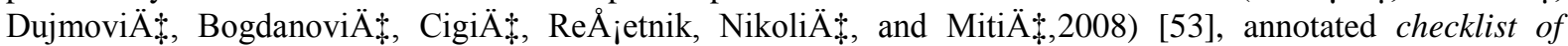
invasive plants in Ethiopia (Binggeli, Desalegn, Healey, Painton, Smith and Teklehaimanot, 2003) [54] and checklist of alien invasive plant species of Georgia (Kikodze, Memiadze, Kharazishvili, Manvelidze and Mueller-Schaerer, 2010) [55] have been done. At the UBGM however, no checklisting of invasive vascular plant species has been done. 


\subsection{Conservation of Biodiversity}

Biological diversity (shortened to biodiversity), represents the very foundation of human existence yet human activities erode this very biological resource (Nyunja, 2007) [56]. According to World Conservation and Monitoring Centre (WCMC) (1992) [7], biodiversity refers to the total variability of life on earth hence includes diversity within species, between species and the ecosystems. According to Global Biodiversity Assessment (GBA), conservation of biodiversity is for public good not only from the standpoint of the species themselves, but for the whole habitat (Heywood and Watson, 1995). It has been strongly recommended that biodiversity be conserved or be sustainably used (UNCED, 1992 [58]; Ludeki, Wamukoya and Walubengo,2006 [59]).According to the ABGN (BGCI, 2011d) [60], plants have a significant place in today's society, not only as a link to our heritage and the traditional use of plants, but also as a basis for economic stability and growth. According to the [4], the role of botanic gardens in plant conservation cannot be over emphasized. The role of in situ and ex situ conservation of plants in botanic gardens is important in safe-guarding the plants, and protecting them from the danger of extinction. GBA stresses the importance of ex situ conservation through germplasm technologies in maintaining genetic diversity [20]. In situ or on site conservation is defined as conservation of biodiversity in their natural setting, allowing us to maintain natural systems and processes. In situ conservation is to allow and enable biodiversity to maintain itself within the context of the ecosystem in which it is found [4]. In situ conservation through encouraging natural regeneration or enrichment planting has the advantage that plants are already well adapted to the environment [22] [23]. However, it may not be possible to raise sufficient materials in situ and domestication of indigenous plants ex situ is the only option left, even though it has not been widely practiced (Cunningham, 1990) [61].

Ex situ conservation, the conservation of species removed from their natural setting, safe-guard the plants even if their natural habitats are destroyed or their populations decimated [4] and is vital botanic gardens' tool in biodiversity conservation. The Botanic Gardens Conservation Strategy (BGCS) states that the purpose of ex situ conservation is to provide protective custody to plants, whose habitats have been damaged, rescue threatened germplasm, produce material for reintroduction and enhance populations as part of ecosystem management for research and education (BGCI, 2011a). Ex situ conservation of wild plants is central and unique role of botanic gardens. The gardens with their facilities and staff expertise are an 'insurance policy' against plant extinction through anthropogenic activities [4]. Arwa (2005) [62] also asserts that conservation is necessary, and people need to be advised on plants of medicinal as well as other values. As exploitation pressure mounts, there is risk of biodiversity loss and hence the need of coming up with various conservation strategies of threatened plants in the garden. In Kenya, much time is spent propagating exotic and commercially feasible plants, at the expense of threatened indigenous plants [21]. As a result, most indigenous plants face extinction if urgent measures of $e x$ situ conservation as well as in situ conservation are not carried out.

\subsection{Threatened Plant Species and Conservation Strategies}

BGCI is the world's largest plant conservation network, and is strategically placed to lead global efforts to reverse the impending extinction crisis faced by the world's plant diversity, and their efforts are focused on securing a future for threatened plant species [4]. Their specific aims are to reverse the loss of key plant species and their habitats, ensure the conservation of threatened plants in ex situ collections, and enhance the conservation and sustainable use of plants that support human well-being and to address the impacts of climate change on wild plants [30]. The International Union for the Conservation of Nature, (IUCN) and the WWF estimate that of the 250,000 species of higher plants known, 60,000 are in danger of extinction or genetic erosion by 2030 (Spellerberg and Hardes, 1992) [63]. Majority of these are in the tropics where species numbers are highest. The local community area around the garden is a home to many plant species. Most of these plants are of high economic value. However, many of them just like in other parts of the world are being overexploited (Achigan-Dako,Pasquini, Dansi and Signigbe, 2009) [64]. Due to population pressures, many are also being cleared to provide space for housing and infrastructure. Most of these plants are therefore threatened or endangered. To save them, the research identified threatened plants found around the UBGM as well as the conservation strategies for implementation to ensure their survival in this rapidly changing world. The strategies are a call to action (Australia Biodiversity Conservation Strategy, 2010). Thus, the study identified and documented priority threatened plants found within North West Kisumu Location, Maseno division of Kisumu county and identified strategies of conservation of these plants ex situ in the UBGM.

\subsection{Education Values of Botanic Gardens}

The botanic gardens have several educational values which benefits many communities. They play important roles in research [4]. A basic understanding of plant diversity is fundamental in ensuring this, and so the role of botanic gardens in research must be fully recognized, appreciated and supported as a vital component in achieving biodiversity conservation. Botanical Gardens' researches in the world include climate change research at the Boston University botanic garden (Primack and Miller, 2009) [65], plant-based research work 
and learning in environment educational setting and exchange of information on genetic resource at Royal Botanic Gardens Edinburgh, Kew (BGEN, 2010) [66]. At the Beijing botanical garden, Educational programmes promote public awareness, knowledge of plants and the importance of their conservation (Shiwei and Zuoshuang, 2006) [67]. At BERC-Til Botanic Gardens in Palestine, educational and research unit carry out applied research aimed at plant conservation using advanced technologies. This unit disseminates knowledge and understanding of the value and importance of plants to the public. BERC-Til Botanic Gardens achieve this through higher education and training, schools education, public education and resources (BERC, 2003) [68].

The UBGM, just like all the botanic gardens throughout the world, is active in undertaking and promoting scientific research on plants and in biological diversity in general. Their collections provide important resources to support such research. The UBGM is active in research in conservation biology, seed and spore biology, rice, and A.I.Vs [1].

\subsection{The Economic Values of Botanic Gardens}

Botanic gardens have several plants within their confines which have numerous economic values. At the University of Newcastle. Upon Tyne, research has been done on the Economic value of botanic gardens: a recreational perspective (Garrod, Pickering and Willis, 1993) [69]. In this research, data on visitors to four very different botanic gardens have been used. The study adopts a travel-cost methodology to estimate the economic benefits which they provide in their role as recreational facilities. At Dumbarton Oaks botanic garden in Washington, research on the aesthetic and economic value of Aztec gardens has been done (Toby, 2007) [70]. The BERC botanic gardens provide a recreation site by making use of plants multipurpose uses and their effects on environmental health and aesthetic values [68]. Many of our resources come from plants and include food, shelter, clothing, fuel and medicine. As much as a lot of research on educational and economic values of various botanic gardens around the world have been done and is still ongoing, no elaborate research and documentation exists on the potential educational and economic roles of the UBGM. This research findings endeavors to enlighten the local and international community on the services provided by the UBGM.

\subsection{Study Area}

\section{Materials And Methods}

The University Botanic Garden, Maseno is located in Kisumu County. The garden is found within Maseno University (Fig.1). The UBGM was established in 2001 as a biodiversity centre for the Lake Victoria region [1]. The garden lies at a latitude of $0^{\circ} 00^{\prime} 16.09^{\prime \prime}$ and longitude of $34^{\circ} 36^{\prime} 08.52^{\prime \prime}$ at altitude of $1500 \mathrm{~m}$. Maseno area receives annual rainfall of about $1346 \mathrm{~mm}$ per year and the average temperature around the garden is $21.2^{\circ} \mathrm{C}$ with $20^{\circ} \mathrm{C}$ minimum and $23^{\circ} \mathrm{C}$ maximum daily temperatures (rice weather station in the garden). Garden size is about 7.0 hectares.

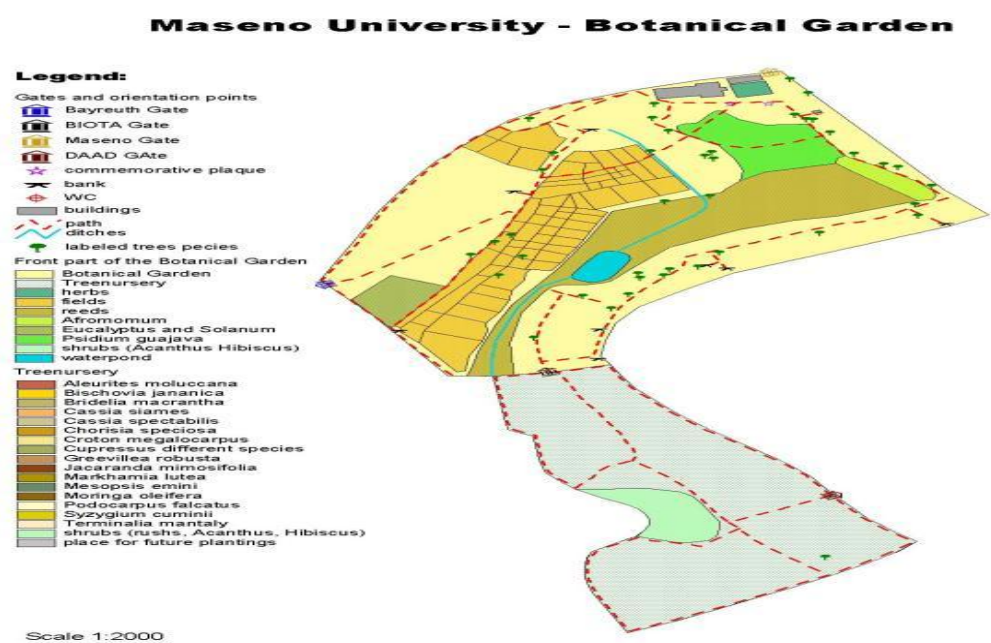

Fig. 1: Map showing the University Botanic Garden, Maseno University, Kenya.

The botanic garden is divided into two major sections, section A with mixed stands and section B with pure stands of plant species. The garden is rich in plant biodiversity, ranging from grasses to trees, edible vegetables, fruits and medicinal plants [1]. The large part of the garden lies in a hilly terrain and serves as a water catchment area for a stream passing through the garden. The garden is interfaced by the local community members, the Luos and Luhyas. The garden is a major biodiversity centre as well as research centre of African Indigenous Vegetables (A.I.V), rice, avocado, medicinal plants and conservation [1]. 


\subsection{Field survey and data collection}

The identification of the plants in the garden was done through the use of taxonomic keys (Noad and Birnie, 1992 [71]; Agnew and Agnew, 1994 [72]; Olembo, Fedha and Ngaira, 1995 [73]) and by oral interviewing of ten University botanic garden staff about their knowledge of plant names and usage [12] (Kokwaro, 1994) [74]. Extensive field notes on the plants were taken and this included; plant habit, sub habit, plant usage, leaf patterns and structures together with a photograph of the plant. This was used to construct annotated checklist of vascular plants in the garden.Purposive sampling was used during field survey where University botany students and staff who are well acquainted with the garden, were identified and a precise questionnaire (attached) administered to them. The precise questionnaire was also used to interview the workers in the botanic garden and members of the community around the garden. A total of 546 individuals (aged 20 years and above) were randomly sampled (Kothari, 2008) [75] from the total population of each of the four categories of persons. Through the questionnaire, information was gathered pertaining to economic and educational values of the garden as well as threatened plants species that need to be conserved in the garden and conservation strategies which should be put in place to save them from extinction.

\subsection{Preparation of herbarium specimen}

Where the identity of the plant was not established, samples for plant specimen in question were collected using secateurs. These were taken to the Maseno University botany laboratory where they were placed inside a folded newspaper then pressed flat by placing within a sandwich of blotter papers and then tied in a plant press and put in a plant drier, where they were dried under standard conditions according to Stace (1993)[76]. They were then taken for identification at the University of Nairobi herbarium and confirmed at the East African Herbarium, Nairobi, Kenya (Sikolia, 2016 [77]; Sikolia, Onyango, Beck and Kinyamario, 2009 [78]). The specimens were then treated by mercuric chloride and stored as voucher specimens at the University botanic garden herbarium (Okello, 2007) [79].The scientific names of plants per family have been listed alphabetically. This is followed by author(s) name(s). Citation of the authority is important for precision purposes. The authors' names are abbreviated according to Brummitt and Powell (1992) [80] unless they are short. The common names of the plants are also indicated. The plant usage in each case are recorded as provided by at least three interviewees out of ten interviewed in the botanic garden and confirmed by Kokwaro (1976) [80] [74], Duke (1992) [81] and Maundu (1999) [82]. The term medicinal has been used to encompass the ethnomedicinal uses of the plants.

Table 1.0 Checklist of plants in the botanic garden showing scientific, common name, family, habit/sub-habit and uses.

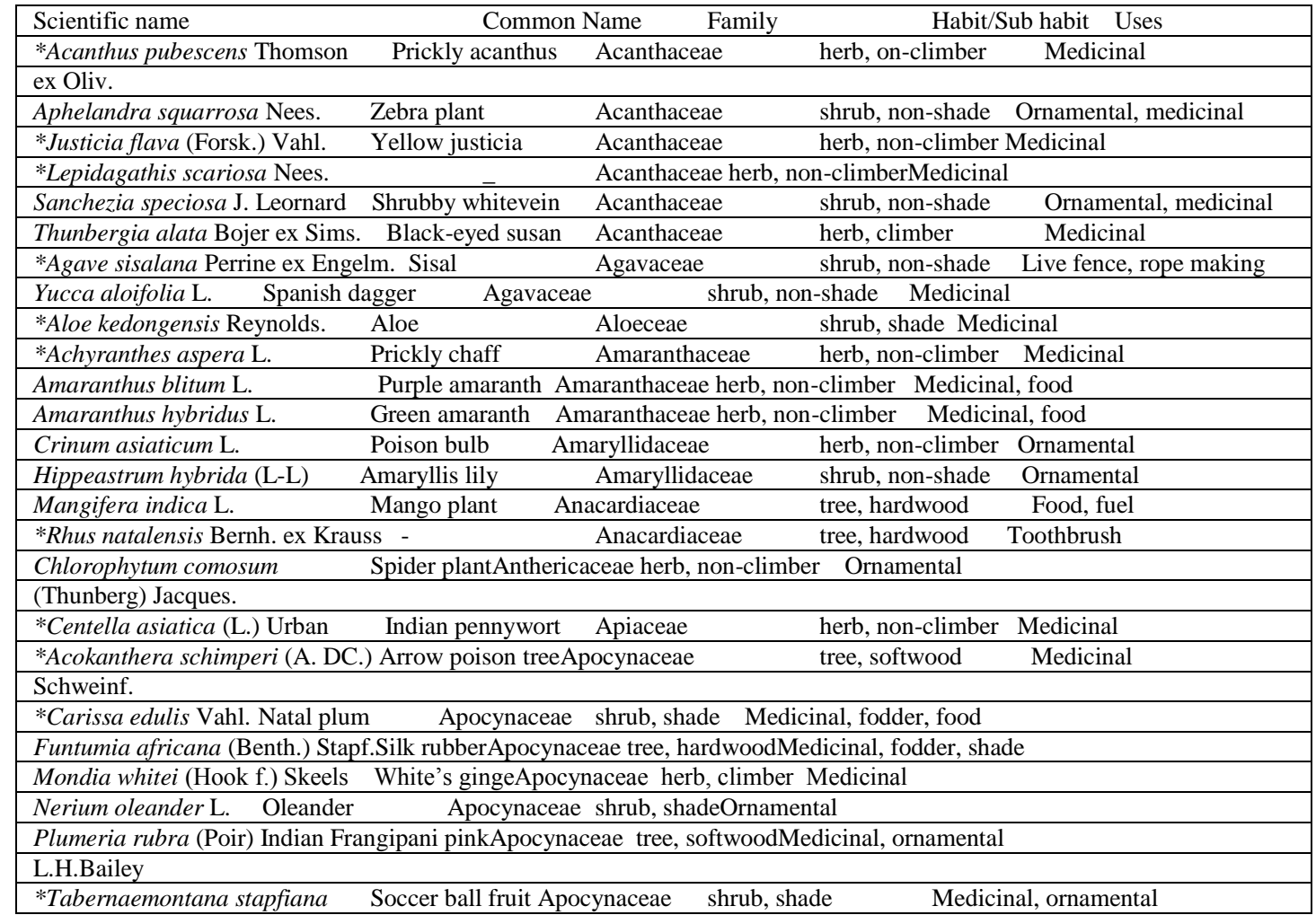


Checklist of plants in the University Botanic Garden of Maseno and their significances to the society

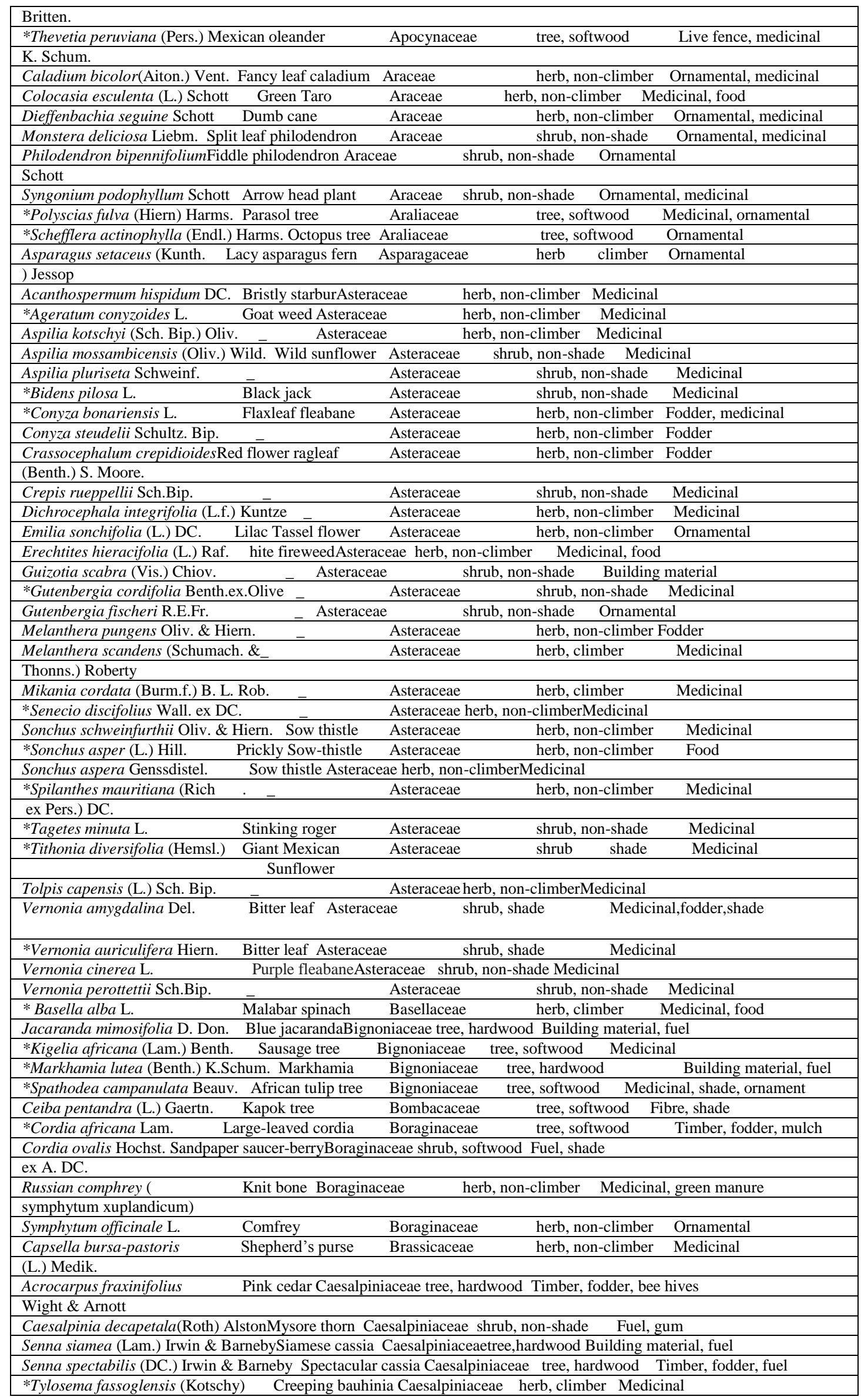




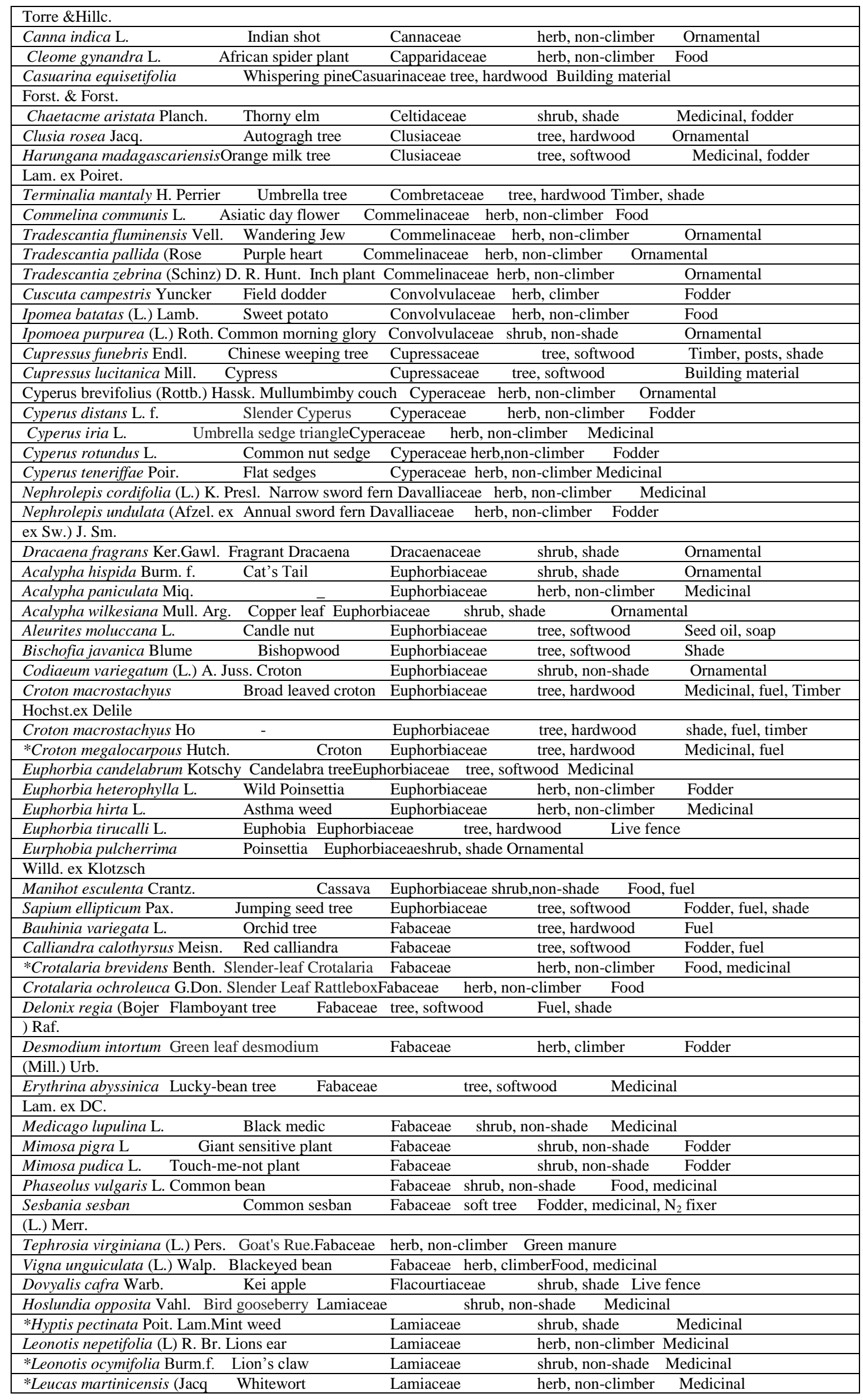




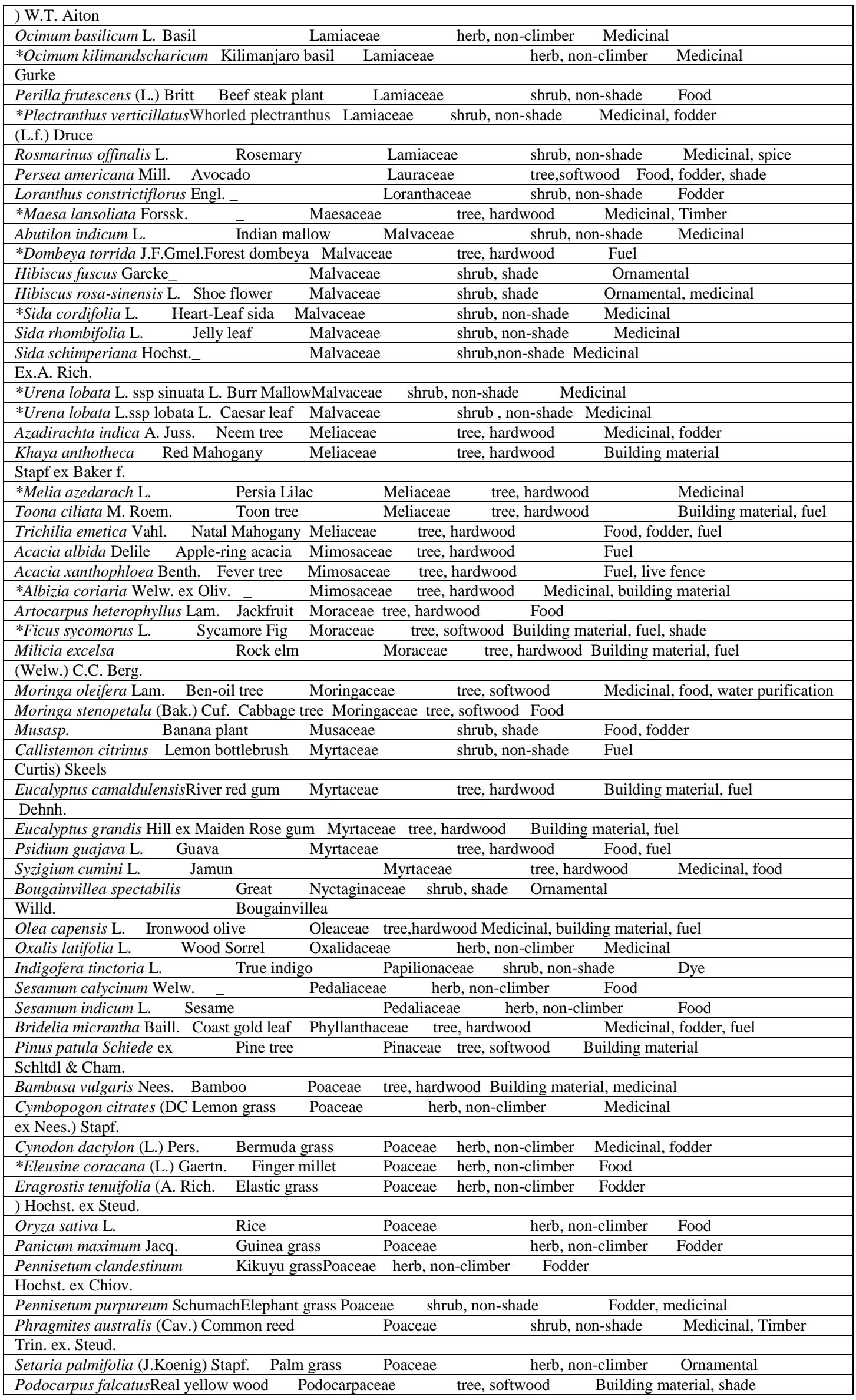


Checklist of plants in the University Botanic Garden of Maseno and their significances to the society

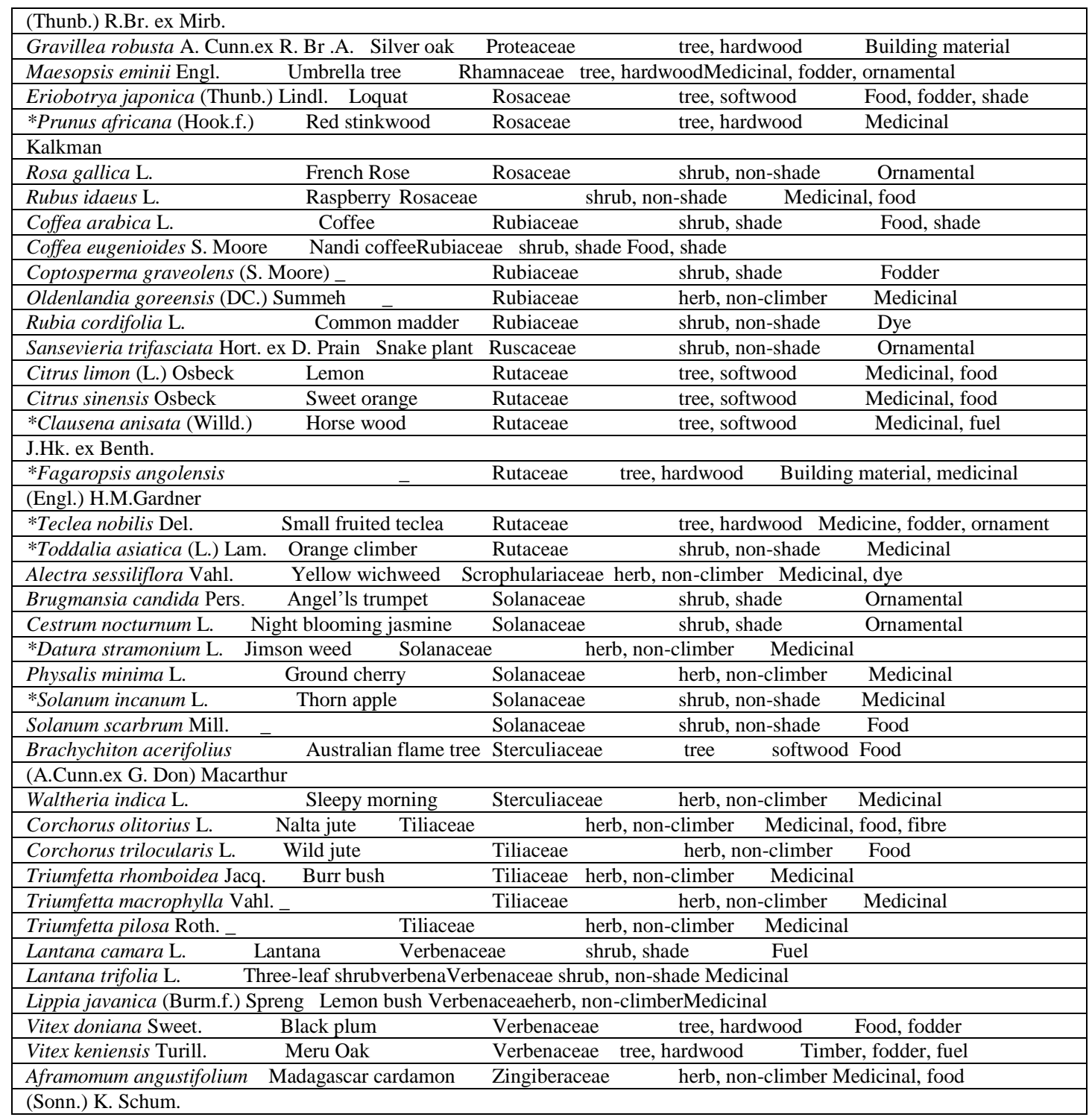

\section{Inference}

A total of 235 plants have been recorded. The plant families in the UBGM are 66, with Asteraceae family having the highest species (32). This confirms the fact that this family has the highest number of plants in nature, i.e. approximately 24000 species and very few of these are classified as trees (Armstrong, 2010) [83]. Euphorbiaceae family is second with 15, followed by Fabaceae with 14 species. Poaceae has 11 species and Lamiaceae with 10 species. The high frequency of these five families can be attributed to the wide spread economic uses of the plants in the families by the local community. The other families have less than 9 species each, apart from Malvaceae which has 9 species. This information has been illustrated using a table of frequency of plants per family

Table 2.0. Frequency of plants per family.

\begin{tabular}{|l|l|l|}
\hline Families & Number of Species & Percent frequency of species \\
\hline Acanthaceae & 6 & 2.6 \\
\hline Agavaceae & 2 & 0.9 \\
\hline Aloeceae & 1 & 0.4 \\
\hline Amaranthaceae & 3 & 1.3 \\
\hline Amaryllidaceae & 2 & 0.9 \\
\hline Anacardiaceae & 2 & 0.9 \\
\hline Anthericaceae & 1 & 0.4 \\
\hline Apiaceae & 1 & 0.4 \\
\hline Apocynaceae & 8 & 3.4 \\
\hline Araceae & 6 & 2.6 \\
\hline
\end{tabular}




\begin{tabular}{|c|c|c|}
\hline Araliaceae & 2 & 0.9 \\
\hline Asparagaceae & 1 & 0.4 \\
\hline Asteraceae & 31 & 13.2 \\
\hline Basellaceae & 1 & 0.4 \\
\hline Bignoniaceae & 4 & 1.7 \\
\hline Bombacaceae & 1 & 0.4 \\
\hline Boraginaceae & 4 & 1.7 \\
\hline Brassicaceae & 1 & 0.4 \\
\hline Caesalpiniaceae & 5 & 2.1 \\
\hline Cannaceae & 1 & 0.4 \\
\hline Capparidaceae & 1 & 0.4 \\
\hline Casuarinaceae & 1 & 0.4 \\
\hline Celtidaceae & 1 & 0.4 \\
\hline Celtidaceae & 2 & 0.9 \\
\hline Combretaceae & 1 & 0.4 \\
\hline Commelinaceae & 4 & 1.7 \\
\hline Convolvulaceae & 3 & 1.3 \\
\hline Cupressaceae & 2 & 0.9 \\
\hline Cyperaceae & 5 & 2.1 \\
\hline Davalliaceae & 2 & 0.9 \\
\hline Dracaenaceae & 1 & 0.4 \\
\hline Euphorbiaceae & 15 & 6.4 \\
\hline Fabaceae & 14 & 6.0 \\
\hline Flacourtiaceae & 1 & 0.4 \\
\hline Lamiaceae & 10 & 3.4 \\
\hline Lauraceae & 1 & 0.4 \\
\hline Loranthaceae & 1 & 0.4 \\
\hline Maesaceae & 1 & 0.4 \\
\hline Malvaceae & 9 & 3.8 \\
\hline Meliaceae & 5 & 2.1 \\
\hline Mimosaceae & 3 & 1.3 \\
\hline Moraceae & 3 & 1.3 \\
\hline Moringaceae & 2 & 0.9 \\
\hline Musaceae & 1 & 0.4 \\
\hline Myrtaceae & 5 & 2.1 \\
\hline Nyctaginaceae & 1 & 0.4 \\
\hline Oleaceae & 1 & 0.4 \\
\hline Oxalidaceae & 1 & 0.4 \\
\hline Papilionaceae & 1 & 0.4 \\
\hline Pedaliaceae & 2 & 0.9 \\
\hline Phyllanthaceae & 1 & 0.4 \\
\hline Pinaceae & 1 & 0.4 \\
\hline Poaceae & 11 & 4.7 \\
\hline Podocarpaceae & 1 & 0.4 \\
\hline Proteaceae & 1 & 0.4 \\
\hline Rhamnaceae & 1 & 0.4 \\
\hline Rosaceae & 4 & 1.7 \\
\hline Rubiaceae & 5 & 2.1 \\
\hline Ruscaceae & 1 & 0.4 \\
\hline Rutaceae & 6 & 2.6 \\
\hline Scrophulariaceae & 1 & 0.4 \\
\hline Solanaceae & 6 & 2.6 \\
\hline Sterculiaceae & 2 & 2.1 \\
\hline Tiliaceae & 5 & 2.1 \\
\hline Verbenaceae & 5 & 2.1 \\
\hline Zingiberaceae & 1 & 0.4 \\
\hline Total & 235 & 100.00 \\
\hline
\end{tabular}

Most plants in the UBGM are mainly herbs at $37.4 \%$, followed by shrubs at $31.9 \%$ and lastly trees at $30.6 \%$ as shown using a pie-chart (Fig.1). 


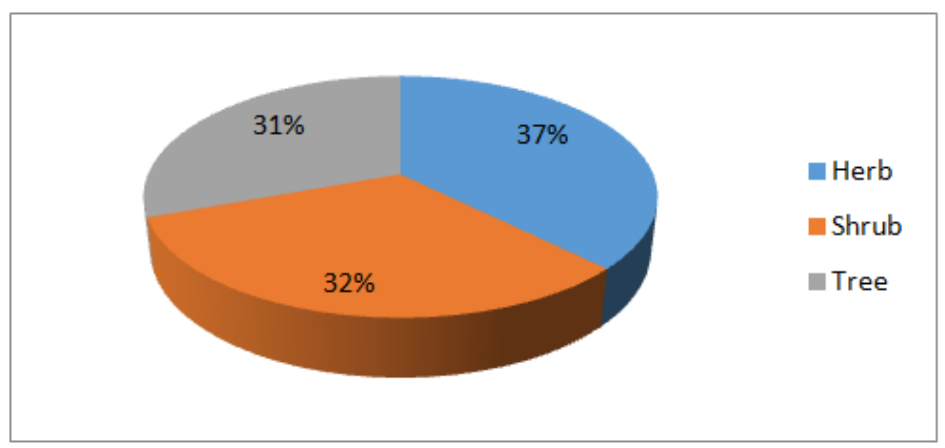

Fig. 1: Pie chart showing percent distribution of the plant habits in the University Botanic Garden of Maseno.

Basing on their habits, plants in the UBGM can further be grouped into various sub-habit categories (Fig. 2). The herbs are categorized as either climbers or non-climbers, shrubs are categorized as either shade or non-shade plants, whereas trees are categorized as either softwood or hardwood. The percent frequency of these sub-habit categories are shown using a pie-chart (Fig. 2).

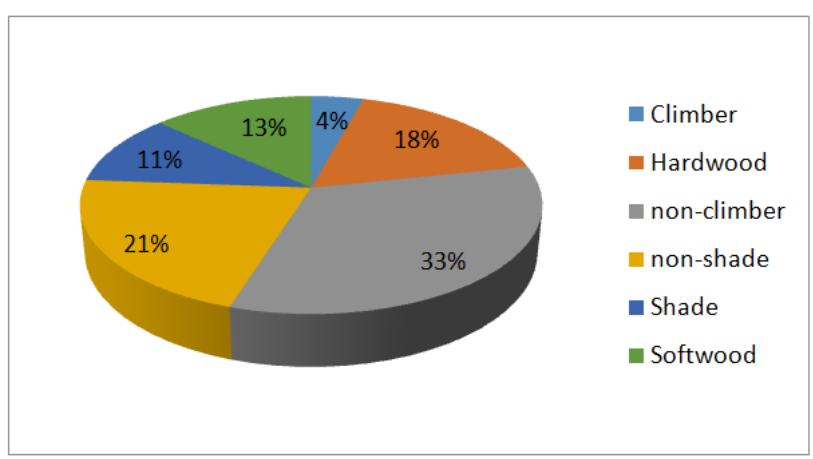

Fig.2: Percent frequency of the plant sub-habits categorization in the University Botanic Garden of Maseno.

The hardwood trees are $18 \%$ whereas softwoods are $13 \%$ of the total plants found in the garden. Hardwoods were mostly angiosperm dicots which are abundant within the tropics. The hardwood showed heartwood (nonconducting wood)subscribed by the sapwood organised externally. This region has undergone visible changes, which involve the loss of reserve food substances and the infiltration of the wood by organic substances (for instance, tannins, gums, oils, saponins and resins) that colour the part dak brown and sometimes make it aromatic. Transvers sections of some of the species indicated the proporton of sapwood to heartwood and the degree of the visible difference between them varies from species to species. However, some species had no clear distinction between the sapwood and heartwood regions.Softwoods are gymnosperms which are slightly less within the tropics. Among the herbs, climbers are few at $4 \%$, with non-climbers being the majority at $33 \%$ of the total plants found in the UBGM. This can be attributed to the fact that the UBGM is within the tropics and has tropical climate, where sunlight energy is adequate all year round to the plants and competition of the same is not so stiff as would be the case in sub tropical regions and dense tropical rain forests. The plants conserved at the UBGM have several economic uses to the local community. This has been illustrated by the use of table of frequency as shown below.

The plant species are used for different functional applications including agricultural (green manure, fodder, soil erosion control measures), construction materials (timber, fencing posts and furniture), industrial products (dye), fibre production, domestic (fuel, shade and live fence), food (vegetables, protein provision and energizers), medicinal including traditional tooth brushes, ornamental, honey source, nitrogen fixers and aesthetic purposes. Medicinal and construction plant materials register $75 \%$ plant usage, whereas 50 being used for other purposes. For example, 120 plants are used for medicinal purposes. This is $51.06 \%$ of the total plants found in the garden. The UBGM has a rich plant biodiversity of ornamental plant species, for instance, 29 plants. Thirteen are not only ornamental but also have other purposes. This gives a total of 42 plants being used as ornamental species. The botanic garden is also rich in plants that provide food. There are 17 plants which entirely provide food while 24 are used for other purposes in addition to food provision, giving a total of 41 plants. Plants used in the provision of building material are 28 in number, 6 provide building material entirely, whereas 22 provide building material in addition to serving other purposes. Fodder, fuel, live fence and shade are three other uses also common among the plants conserved in the botanic garden. 5 plants have unique uses 
such as provision for green manure, dye, oil and toothbrush. From the data of checklist of plants, it's evident that most plants have more than one use.

\subsection{Threatened plants and conservation strategies}

According to Mendonça,Windham-Bellord, Andrade and Veríssimo,(2011) [84], conservation is one of the key roles of botanic gardens as outlined by the GSPC. In recent decades, the phenomenon of expanding the powers of the botanic gardens has been occurring, especially, under agreements and international conventions that deal specifically with biodiversity conservation. The United Nations Convention on the Biological Diversity (CBD) based the editing of the International Conservation for Botanic Gardens document that discusses the various aspects of these institutions mission, emphasizing one of their roles to be conservation [84].In the areas around the UBGM, just like in many other parts of the world, the survival of plants has been threatened. From the findings, medicinal plants are the most threatened at $43 \%$ followed by food plants at $32 \%$, followed by plants that provide timber, fuel and shade at 19\% (Fig. 3). Ornamental plants account for the least number at $6 \%$. This observation could be attributed to the fact that the local community around the garden still relies on herbal medicine for treatment of most diseases (Pers, Com.) and so these plants are over exploited. The community members also utilize the food plants so much and this over exploitation makes these plants to be threatened. Ornamental plants are not so commonly valued and planted by the community members around the botanic garden. Their aesthetic values seem not to be appreciated and this explains why a small percentage is reported to be threatened.

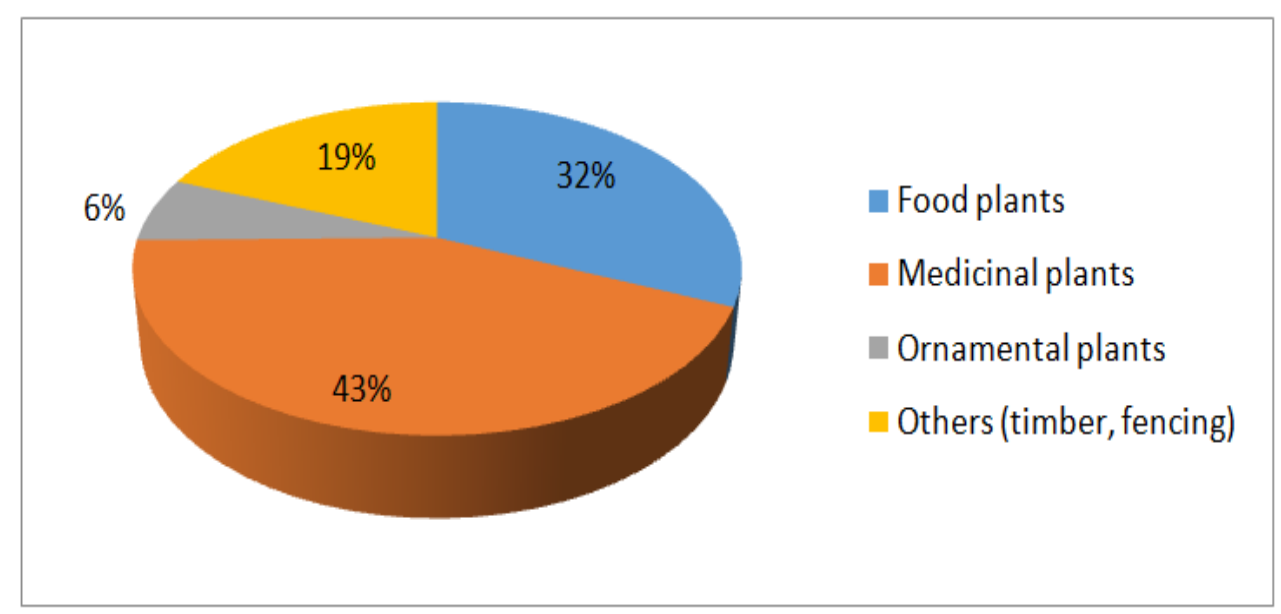

Fig. 3.0 Usage of threatened plant species in the University Botanic Garden of Maseno

Overall 24 species were reported as threatened, but amongst these only a few species were reported as threatened by a reasonably high number of respondents. Other than the threatened plants mentioned above, respondents also pointed out that there were other plants that they wished could be conserved in the UBGM.Most respondents cited medicinal plants like Senna didymobotrya, Maerua spp, Aloe vera and Zanthoxyllum spp. Food plants such as Cucurbita pepo, Passiflora edulis and various species of leafy vegetables such as various varieties of Brassicaoleracea, Spinacia oleracea

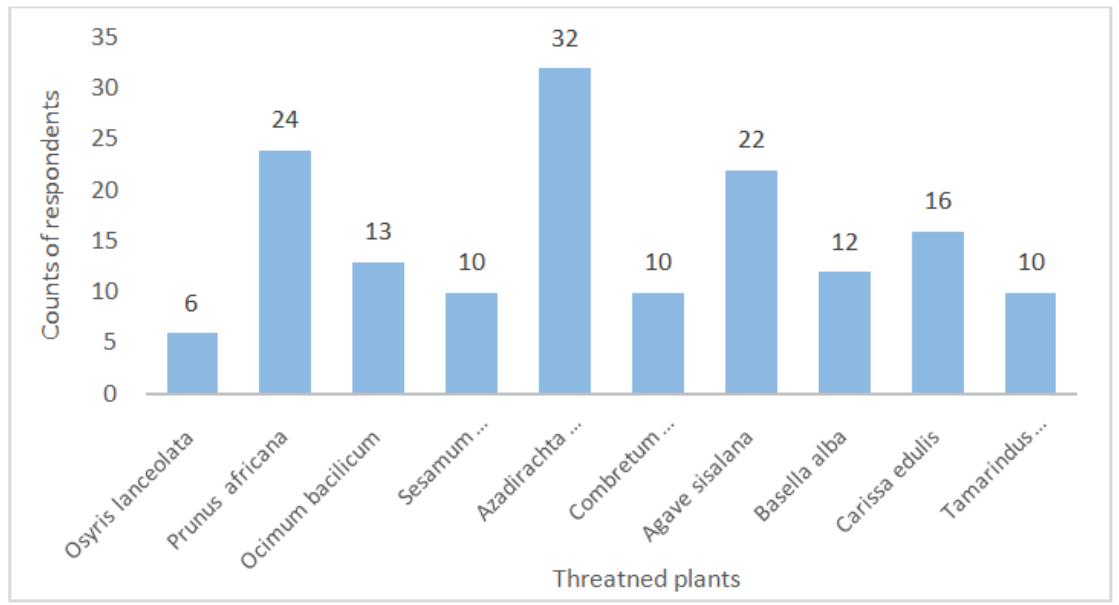


Fig. 4: Most threatened species (respondent perception) around the University Botanic Garden of Maseno

well as ornamental plants, were also recommended to be grown in a greenhouse within the UBGM.The findings indicate that most plants are threatened due to over exploitation. This has been supported by [64] in their study of traditional vegetables of Benin. The plants are over exploited due to their medicinal significance, food provision, trade, firewood, charcoal burning and timber. The present study show that over exploitation account for $35 \%$ of the reasons for the plants being threatened, followed by habitat loss due to clearance of land for infrastructure, agriculture and building (30\%), then climate change (12\%) (Fig. 5). 23\% of the respondents attributed the threatening of plants to a combination of factors such as pollution and disease, over exploitation and climate change. No respondent attributed the threat to invasive species.

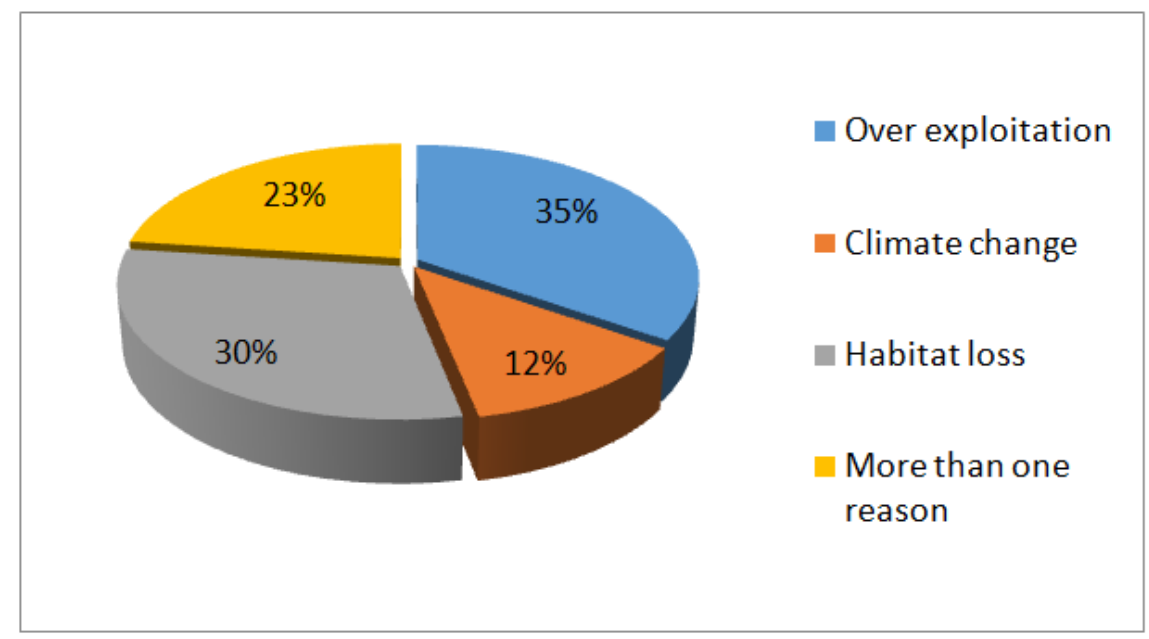

Fig. 5: Causes of plants being threatened around the University Botanic Garden of Maseno

Plants are important to humankind not only economically, environmentally and industrially but also spiritually, historically and aesthetically, for they sustain human life through direct and indirect gains by providing a wide range of products for survival and prosperity (Seth, 2004) [85]. Their conservation is therefore imperative. As exploitation pressure mounts, there is risk of biodiversity loss and hence the need of coming up with various conservation strategies which if implemented will save the threatened plants from extinction. The findings indicate several strategies of conservation of these threatened plants. $35 \%$ of respondents suggested raising of propagules (seeds) from these plants and storage of these seeds in a seed bank within the UBGM (Fig.6). This strategy is in line with the one being carried out at Til-Berc botanic gardens [68]. These seeds can then be sold to the community members when need be. Nurseries for these plants should be raised and people, organizations and institutions encouraged to plant them. This strategy is in line with the one given by respondents in a near similar line of study in Benin [64].24\% of the respondents suggested that education was the most appropriate strategy for conservation of these plants (Fig.6). The UBGM staff members should embark on educating the community members on the usefulness of these plants and the need to exploit them sustainably. The people should also be educated on how to harvest medicinal plants. Only trees over 30 years should be harvested for timber, and "cut one plant two strategy" should be adopted in order to save these plants from extinction. The other strategy that was suggested by the respondents was government ban on use and trade of rare plants and their products (Fig.6). 21\% of the respondents observed that this was to allow these plants to increase in population so that when the ban is lifted, the plant population could be sufficient to meet the needs of the users. Non-the-less, upon the government lifting the ban, it should still regulate the use of these plants. A good example was Osyris lanceolata which is treasured for its essential oils used in perfumery as well as its timber (Wildlife direct, 2009) [86].

Despite majority of the respondents suggesting the above strategies, $8 \%$ of the respondents suggested other strategies such as domestication of wild plants, where there would be selection and replication of cultivars with desired traits and genetic suitability for domestic conditions as this would ensure their regeneration and availability [64]. The other strategy suggested by $6 \%$ of the respondents was protecting the natural environment from activities such as quarrying, destruction of forest, land clearance etc. Through such protection of the environment, the plants will also be protected. 


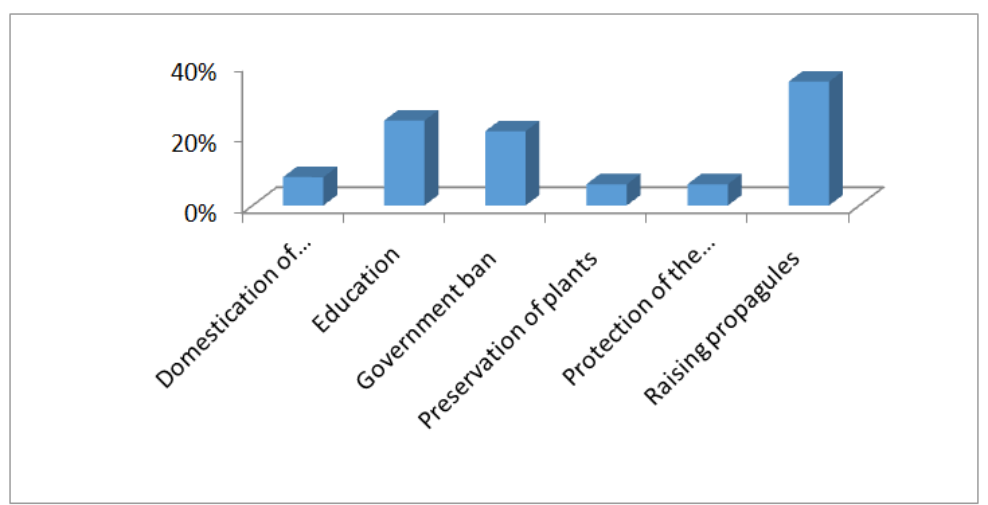

Fig. 6: Conservation strategies of threatened plants

Preservation of the plants in the UBGM was another strategy suggested by the 6\% respondents. Preservation means put aside and in this case the respondents used it to imply that the threatened plants should be planted ex situ in the botanic garden where their conservation is guaranteed. There is, therefore an urgent need to adopt the replanting of these species not only in the botanic garden but also on the farms where they can readily be accessed by people. In addition, policies to support the replanting of these trees should be adopted and implemented (Maundu and Tengmas, 2005) [87].

\subsection{Checklisting and Invasive Species}

\section{Discussion}

Checklisting of plants has revealed several vascular non-invasive and invasive plants found in the UBGM. The botanic garden has a rich floral diversity of 235 plant species, 3 of which are invasive. Herbs account for the highest number at 88 plants, followed by shrubs at 75 plants whereas trees are 72 plants. Most of the herbs and shrubs are perennials and are mostly found growing during short rainy season experienced during August to October, and long rainy season experienced during March to July (Lwande, 2008) [88]. Plants from the Poaceae, Cyperaceae, and Asteraceae families are the most affected by these weather changes. Their vegetative body parts die off, but when it starts to rain, their underground corms (for Poaceae and Cyperaceae families) and burrowed seeds (for Asteraceae, herbs and shrubs from other families) sprout again. Weather therefore is a major factor in determining plant species availability in the botanic garden at any given time.

Slashing and other forms of land clearance is a major setback in the conservation of plants in the botanic garden. During slashing, many herbs and shrubs are cleared, making these plants to be unavailable in the botanic garden. Therefore any researcher or person interested in these plants may not access them all year round in the botanic garden. Examples of such plants include Physalis minima, Datura stramonium, Solanum incanum,Triumfetta rhomboidea,Tradescantia fluminensisand Ocimum basillicum. The plant checklist has revealed three invasive plants found among the ex situ plants conservation. From the research, three invasive species are recorded; Phragmites australis, Basella alba and Lantana camara. Even though botanic gardens are centres of plant conservation, they can be potential hotbeds for future plant invasions (Lechner and Kiehn, 2010). Many invasive species have been introduced in many botanic gardens via the horticulture trade during years of plant exploration and movement of plants around the world (Clubbe, Hamilton and Corcoran, 2010) [89]. Thus botanic gardens have a high responsibility to monitor their holdings carefully for potential invasive [18].

Phragmites australis, also referred to as common reed grass is a tall, invasive perennial wetland grass ranging in height from 3-15 feet. The plant produces horizontal rhizomes that grow on or beneath the ground and produce roots and vertical stalks (culms). The rhizomes allow the plant to form large colonies. The stiff, hollow stalks support leaf blades which are smooth, broad and flat. A large terminal inflorescence (panicle) is produced and is purplish in flower and grayish in fruit. Large quantities of seed are produced, however, most or all of the seed may not be viable (Biodiversity database program, 2007). The invasiveness of this plant is confirmed by its presence in the database of invasive plants of Ohio (Biodiversity database program, 2007) [90]. This plant is prevalent in open wetland habitats and favors alkaline and brackish waters. These areas include elevated areas of brackish and freshwater marshes, along riverbanks and lake shores and almost anywhere there are slight depressions that hold moisture. The species is particularly frequent in disturbed or polluted soils along roadsides, ditches and dredged areas. It is also known to tolerate highly acidic conditions (Biodiversity database program, 2007) [90]. In the UBGM, these plants grow along the stream bank, and into the cultivated areas where they are mechanically cleared by cutting and digging them out (Lapin and Randall, 1994) [91]. Invasive stands of common reed grass eliminate diverse wetland plant communities, providing little food or shelter for wildlife [90]. 
Basella alba is another invasive plant found in the botanic garden. This is an economically important plant, which is consumed by breastfeeding mothers to increase the milk [21] [77]. This plant is however invasive, and in the UBGM, the plant being a climber, intertwines around the Phragmites australis, Vitex doniana, Vitex keniensisSapium ellipticum and many other plants, forming a carpet-like surface. Invasive species are known to cause great economic, health and ecological problems all around the globe [19]. The UBGM is no exception. The carpet-like surface hinders other herbs and shrubs from growing beneath it thereby causing serious ecological problem. The invasiveness of this plant is confirmed by its presence in the Taiwan invasive species data (Taiwan invasive species database, 2009) [92]. Lantana camara is believed to be indigenous to the Lower Rio Grande Valley of Texas in the United States (Hagne, 2009) [93]. It has become naturalized in tropical and warm regions worldwide (Florida Exotic Pest Plant Council, 2005) [94]. It has been introduced into other parts of the world as an ornamental plant and is considered an invasive species in many tropical and sub-tropical areas (New South Wales National Parks and Wildlife Service, 2007) [95].Lantana camara is grown as hedge plant and has various medicinal and other uses. The methanolic extract of Lantana camara leaves has shown healing of gastric ulcers (Sathisha, 2011) [96]. Extracts of the fresh leaves are antibacterial and are traditionally used in Brazil as an antipyretic and in the treatment of respiratory system infections (Barreto, Sousa, Campos, Costa and Rodrigues, 2010). Lantana camara is an invasive species and has covered large areas in India, Australia and much of Africa (ISSG database, 2012) [98]. It colonizes new areas when its seeds are dispersed by birds. Once it reaches an area, Lantana camara spreads quickly. It thrives so well, that efforts to eradicate it have completely failed. It is resistant to fire and quickly grows in and colonizes burnt areas (Ankila and Sundram, 2005) [99]. It has become a serious obstacle to the natural regeneration of important native species including the Shala Tree (Shorea robusta) in Southeast Asia, as well as plants in 22 other countries [94]. In the UBGM this plant has colonized much of the garden especially the hedges, where it has thrived well, regenerating very fast and forming monocultures, so that they are the only major plant growing there. These plants grow very quickly preventing light reaching slower growing or shorter plants and so causing those less aggressive plants to die off.

There are many hypotheses for why we have an alien invasive plant problem all over the world in the flower beds, gardens, parks and in botanic gardens. However, for each hypothesis, the cause relates either directly or indirectly from the activities of humankind. We have created a small, interconnected world, and botanists, horticulturists, and botanic gardens have eagerly cooperated in the process. Botanic gardens are a small but significant part of the invasive plant problem. Yet botanic gardens are also leaders in good practice for horticulture and conservation and can play an important role in educating the public. The UBGM is no exceptional and should educate the public about the ecological dangers brought about by invasive plants and appropriate measures that should be put in place to curb their spread.

\subsection{Educational values of the University Botanic Garden, Maseno 4.2.1 Centre for research}

The UBGM has several educational values which benefit many researchers as well as local and international communities. According to [30], the role of botanic gardens in research must be fully recognized and supported as a vital component in achieving biodiversity conservation. The UBGM, just like all the botanic gardens throughout the world, is active in undertaking and promoting scientific research on plants and in biological diversity in general. Their collections provide important resources to support such research. The UBGM is currently active in research in various areas. A significant number of the respondents observed that the UBGM is actively involved in adaptability or suitability trials on rice varieties, African indigenous vegetables research where vegetables such as Solanum scarbrum, Cleome gynandra, Corchorus olitorius and Crotalaria brevidens are mostly planted. Conservation biology where research on in situ and ex situ plants is carried out as well as seeds stored in seed banks in the UBGM is also studied. An insignificant number cited maize research. A significant number of the respondents however stated both rice and A.I.V as the main research projects that they are aware of. Although not all botanic gardens have the resources (staff, facilities and expertise), to enable them play major roles in botanical research, all can contribute to such research by making their facilities and collections available to researchers [30]. The UBGM is also a centre for most Botany and Horticulture post graduate research projects. Some of these research projects include 'Evaluation of rainfall use efficiency and water extraction limits by upland rice grown under different field management practices in western Kenya,' and Efficacy of Acremonium zonatum (SAWADA) Gams Formulation on the biocontrol of water Hyacinth (Eichhornia crassipes) and its effect on non-target plants. Despite being a centre for research, little is known on whether this botanic garden has developed any new plant variety which is commercially available. This is supported by the fact that only an insignificant number of the respondents said they knew. A significant number however said no or said they were not sure. The respondents who answered on the affirmative cited rice and maize as the only plants where new varieties had been developed.

The UBGM was started as a biodiversity centre, with one of the aim being to assist the local community members around it [1]. The research activities going on in it have had positive impacts to the 
community around (Pers.Com). Majority of the respondents cited employment as one of the key benefits that the community members have gained from these ongoing research projects. The rice and A.I.V.s projects for example provide employment to over fifteen individuals in the UBGM, whereas maize research provides employment to about ten individuals. These individuals prepare the land, weed and water the plants, as well as assist researchers who measure certain parameters such as water stress, chlorophyll amount from the plant. Conservation of plants is another key benefit cited by the respondents as a key benefit. Some of these plants conserved in the UBGM are threatened with extinction and are rare. Such plants include Azadirachta indica, Prunus africana and Moringa oleifera. These conserved species provide samples for propagation and use. The respondents also cited dissemination of seeds as another benefit to the community. The stored seeds in the UBGM seed banks such as seeds of Solanum scarbrum are availed to the locals when need be since some of these seeds are not found readily in the local market. Lastly education was cited as an important benefit that the local community members have enjoyed. They are taught on how to propagate various crops such as rice and A.I.Vs. This is done through seminars and workshops.

\subsubsection{Information exchange}

The UBGM plays an important role in information exchange. It holds important information relating to biodiversity. Its research programmes yield information vital to support biodiversity conservation. According to [4], botanic gardens currently undertake, facilitate and support the exchange of such information by means of their publication, on the internet, and by providing access to their databases. Information about some of the plants conserved in the UBGM can be accessed from various publications [1] [21] [62] [77], and on the internet websites.

\subsubsection{Public Education, Awareness and Learning}

This is another important educational role of UBGM. The Convention of Biological Diversity and agenda 21, resulting from Earth Summit held in Rio in 1992 [4], highlighted the importance of public education and awareness in promoting sustainable development and improving capacity of people to address environment and development issues. The UBGM plays such crucial role in creating such public awareness and education especially to the University students, staff, local community members as well as many high and primary schools students who visit the garden to acquire knowledge. The UBGM executes this role by means of holding seminars on various topics such as 'Environmental Change Impacts on Species distributions - The Role of Models,' 'Subtropical Savanna. Structure and Function with respect to productivity and grazing,' and 'Vulnerability of man-made savannah "Montado Ecosystem critical influences on carbon balance and production.' Through these seminars causes of various biodiversity threats are addressed. According to the article 'The Potential Role of African Botanic Gardens Environmental Awareness Programmes and the need to be involved' African Botanic gardens remain some of the only few places where the continent's natural plant richness has been preserved and are thus the present windows to the wonders of the plant kingdom [BGCI, 2011]. They are excellent centre for education and resource centre for plant conservation and development.

The UBGM also provides learning structures and facilities to the students and lecturers. The respondents pointed out seminar halls and post graduate rooms as important structures where learning occurs in. Keeping plants in a child's learning environment enhances learning capabilities by helping them to focus and concentrate. This improves their ability to learn new things and makes it easier for them to absorb and retain information [100]. Ornamental plants and other trees found in the UBGM are not only a source of recreation and pleasure but also educate people when visitors in gardens wish to know the names and uses of such trees [85].

\subsubsection{Plant conservation}

This is the key role of the botanic gardens worldwide [4]. The UBGM is no exception as 235 plant species are reported in the checklist database as species conserved in situ and ex situ in the UBGM. A significant number of the respondents reported that UBGM is an excellent centre for plant conservation. UBGM is closely associated with University and therefore have special opportunity to undertake or develop research programmes that support plant conservation. The UBGM should however endeavor to preserve a single representation of each local indigenous flora. The UBGM is an ex situ centre for conservation of plants from the region from such places as Kakamega Forest, Mt. Elgon and the Sacred Sites [56]. The garden is significant since it holds hope to some threatened plants from the region and beyond considering that the area is populous and previously known forests have since disappeared, for instance Maragoli Forest [56].

\subsubsection{Plant identification}

Plant identification is another crucial role of the UBGM. Most of the respondents stated that the UBGM plays crucial role in assisting in plant identification. The garden is rich in floral diversity conserved both in situ and ex situ, with these living collections as the primary plant identification resource [67]. The UBGM 
should however, support their interpretation through a variety of means including plant labelling, a range of displays and visitor programmes [67]. These conserved plants can assist in the identification of unknown plants collected from other ecological zones of Kenya and beyond.

\subsection{Economic values of the garden 4.3.1 Provision of food}

According to UNEP, FAO, and the WCU, biodiversity has several economic values which can be divided into two broad categories; Direct and indirect economic values [20]. The direct economic values include provision of food. $48 \%$ of the respondents reported that they had used plants from the UBGM. Of those who reported on the affirmative, $46 \%$ reported that they had used food plants. The UBGM has a rich biodiversity which provides foods such as bananas from Musa spp, vegetables such as Cleome gynandra, Crotalaria brevidens,Corchorusolitorius,Solanum scarbrum and Sesamum calycinum [1] [84] and fruits such as guava and mangoes from Psidium guajava and Mangifera indica species respectively. 52\% of the respondents however said they had not used any plant from the UBGM.

\subsubsection{Source of medicine}

The UBGM is rich in medicinal plants. One of the more obvious benefits of plants and trees is that many of them have valuable medicinal properties [100]. Cultivating plants provides opportunities for additional scientific studies of the possible positive medicinal values of plants. Natural herbal remedies are simple and holistic methods for treating common illnesses and maladies [100]. Biodiversity's relevance to human health is becoming an international political issue as scientific evidence builds on the global health implications of biodiversity loss [20]. Majority of plants in the UBGM have medicinal active components. Worth noting is the fact that a significant number of the respondents cited medicinal plants as the plants they had used from the garden. Examples of these commonly used medicinal plants include Markhamia platycalyx used in the treatment of throat diseases[80], Tithonia diversifolia, whose leaves are crushed and boiled and taken as a remedy for stomach upsets, Carissa edulis whose roots are boiled and the resulting concoction taken to relieve lower abdominal pains during pregnancy [80]. Others mentioned were Moringa oleifera and Azadirachta indica both whose leaves are boiled and the resulting concoction taken to relieve general body weaknesses, fever and digestive tract infections (respondent perceptions).

\subsubsection{Carbon sequestration and micro climate}

This is one of the indirect economic uses of biodiversity. Plants play important roles in carbon sequestration and ensuring improved air quality[20] [85]. Plants absorb much of the world's carbon in form of $\mathrm{CO}_{2}$ gas. A significant number of the respondents cited carbon sequestration as one of the roles that plants in the UBGM play towards climate change. Through Carbon sequestration, stabilization of climate and maintaining chemical balance of earth occurs. Trees and other plants are crucial to the sequestration of carbon from the earth's atmosphere and play an important role in reducing the urban and rural carbon footprint [100]. Trees are known to abait or moderate environmental temperature [85], by absorbing $\mathrm{CO}_{2}$ which is a greenhouse gas that contributes to global warming. Research has shown that large trees can absorb significant amounts of carbon from the atmosphere each year, as the tree absorbs carbon (iv) oxide and release oxygen through respiration. As such, trees and other landscape plants serve as an important tool in improving air quality in nature [100]. Trees and landscape plants also help to absorb odors and potentially harmful chemicals in the air. The recent phenomenon of global warming is as a result of biodiversity destruction[20]. The loss of forests and woodland around the world is a serious issue. It can contribute to changes in rainfall patterns, temperature, wind speeds, aridity, flooding and soil absorption characteristics [20].The burning of forests releases carbon into the atmosphere. If this exceeds growth rate of plants, and if the oceans (which store much of the world's carbon) are not able to store this additionally released carbon [20], this could contribute to altering the chemical balance of the earth as a result of global warming. The climate is more labile and any sustained perturbation will alter succession dynamics because of the novel combination and intensity of constraints, may be quite different in both direction and intensity to those previously observed [5]. If the plant biodiversity is destroyed, there will be no plants to absorb $\mathrm{CO}_{2}$ gas. Plants therefore play important roles in ensuring the right amount of $\mathrm{CO}_{2}$ exists in the atmosphere, and therefore by extension ensuring that there is stability of climate and chemical balance of earth. Respondents also observed that formation of micro climate is a key relevance of the UBGM to the local community. The UBGM has created a micro climate in Maseno. Maseno area receives annual rainfall of about $1346 \mathrm{~mm}$ per year (rice weather station in the garden) whereas the neighbouring areas around it such as Chulaimbo receives mean annual rainfall of about $1250 \mathrm{~mm}$ [88]. The average temperature around the garden is $21.2^{\circ} \mathrm{C}$ with $20^{\circ} \mathrm{C}$ minimum and $23^{\circ} \mathrm{C}$ maximum daily temperatures (rice weather station in the garden) whereas as Chulaimbo, has annual mean daily minimum and maximum temperature ranges of $10-30^{\circ} \mathrm{C}$ and $26-36^{\circ} \mathrm{C}$ respectively [88]. 


\subsubsection{Protection of water sheds and soil}

Protection of water sheds and soil is a key role of plants. Significant number of respondents observed that the plants hold soil particles firmly [100]. When trees are removed, torrents of water are allowed to run unchecked down steep hillsides, causing avalanches and flooding [20]. Forests are also natural means of water management. The hilly terrain part of the University Botanic Garden is a water catchment area for the stream passing through it and helps in the maintenance of the hydrological cycle. Without plants therefore, the water cycle will be interrupted, leading to aridity. The stream currently has water all year round, in contrast to seasonal drying cycles it used to go through during dry months of the year before the garden was established. Many plants are also found growing along the stream bank, most of which would be missing if it were not for the stream.

\subsubsection{Maintenance of the nutrient cycle}

The nutrient cycle is maintained by the biological species. When living organisms die, their bodies are broken down by decomposers such as the bacteria and Fungi. Through decomposition, nutrients locked up in the bodies of organisms are unlocked and let to flow in the natural biological system, from where other organisms can access and use them [20]. The respondents observed that nutrient cycling was key to conservation of biodiversity. When the botanic garden plants die off, they decompose and other organisms utilize nutrients from their bodies, thereby perpetuating their survival.

\subsubsection{Home for rare and many other species}

The UBGM is home to millions of forms of life, ranging from herbs to giant trees like Toona ciliata. The respondents observed that rare plant species like Moringa oleifera, Prunus africana and Azadirachta indica are conserved in the UBGM. The University Botanic Garden is inhabited by many kinds of organisms from Animalia kingdom ranging from small insects to monkeys. So when forests disappear, so do their inhabitants [5]. This therefore calls for need of conserving the biodiversity to avoid loss of such organisms.

\subsubsection{Attraction of recreational and scientific tourism}

The UBGM is fairly large, about 7 hectares, but nevertheless it is a source of attraction to the local community members who visit it for recreation as well as University staff, university and high school students who come to acquire scientific knowledge and enjoy the tranquil conditions that prevail there. Members of the international community also visit the UBGM with the aim of acquiring scientific knowledge and recreation. This probably explains why the garden is a centre for international rice research. The UBGM is rich in ornamental trees that have showy flowers [85] such as Canna indica, Plumeria rubra and Scheffleraactinophylla and other plants which have bioaesthetic values which attract many people to it. The UBGM provides them with an inexpensive (often free) and convenient recreational service [85](Hall and Dickson, 2011) [100]. There is a positive correlation between the presence of a botanic garden or park in a neighborhood and the level of physical activity of the residents. People are much more likely to exercise when there is a no cost, aesthetically pleasing area or facility for them to use [100]. Trees found in the botanic garden are a source of recreation and pleasure.

\section{Conclusion, Recommendation And Suggestions}

The research has provided a detailed and comprehensive checklist of the plants found within the UBGM. A total of 235 plant species were checklisted, together with their habits, common names, uses and brief descriptions. Three invasive species are recorded. Relevant conservation strategies for adoption to save the endangered plant species from extinction are pointed out. The botanic garden offers educational and economic values to the students, staff and to the community in general. This knowledge enhances better understanding of the services provided by the botanic garden. UBGM is an effort towards the Nagoya Protocol to ensure the implementation of the third objective of the Convention on Biological Diversity - fair sharing of the benefits arising from the utilisation of genetic resources (Access and Benefit Sharing, ABS) - and thus contribute to global conservation of biodiversity and sustainable use of its components. This organized, planned, programmed and wealth of the indigenous knowledge of plants especially medicinal plans is a great potential for mainly research and discovery of new valuable drugs to fight against diseases as austerity safe measures towards drug resistance and for posterity.

While significant steps have been made in various botanic gardens around the world to address the problem of invasive plants, at the UBGM not a lot has been done. Research on these plants will enhance a clearer understanding of the mechanisms that result in them being invasive, thereby controlling their spread. Most of the plants in the UBGM have medicinal properties as recorded. More research on these plants need to be undertaken, especially on the plants that have not thoroughly been studied. Further studies are recommended 
on such plants in order to isolate, identify, characterize and elucidate the structure of their bioactive compounds and consequently efficacy studies be carried out to establish the actual mode and mechanism of action.

The community members in and around Maseno are the main custodians of the conservation strategies as identified in the research, as well as other data related to plant conservation as collected through the questionnaire. Consequently any benefits that may accrue from the use of this knowledge must be shared with them. The UBGM should sensitize people more on its significance and services provided by it. This will ensure more individuals enjoy the benefits provided by it.It is suggested that more research should integrate the phytochemical researches and accruing virtues to the society. Finally, the progress and sustainance of the similar botanic gardens worldwide will need fully support from established botanic gardens, especially in training personnel capacity and infrastructure support.

\section{Acknowledgements}

Am grateful to Seline Omondi and Peter olewe for their effort during the research work. Further, am indebted to the staff of department of botany, Maseno University for their assistance in the course of the research studies. The University Botanic Garden of Maseno staff is also appreciated for their services.

\section{References}

[1]. Onyango, M. A. O. and Onyango, J. C., Conservation and seed production of African Leafy vegetables at Maseno University botanic garden, Kenya. African Crop Science Conference Proceedings, Vol. 7. 2005, 1201-1204.

[2]. Wikipedia Encyclopedia,http://en.wikipedia.org/wiki/Botanical-garden\#cite-note. Accessed on 14/8/2011, 2011a.

[3]. Swaminathan, M. S. and Kochhar, S. L., Plant and Society (London, Macmillan Publishers Limited, 1989).

[4]. BGCI, International Agenda for Botanic Gardens in Conservation. Accessed on 19/06/2015.

[5]. Frankel, H. O., Brown, A. H. D. and Burdon, J. J.,The Conservation of Plant Biodiversity. (Cambridge University Press, 1995)

[6]. Wikipedia Encyclopedia,http://en.wikipedia.org/wiki/Biodiversity. Accessed on 19/10/2011, 2011c.

[7]. BGCI,African Botanic Gardens Network.http://www.bgci.org/ourwork/gspc/, accessed on 16/07/2011, 2011e.

[8]. Sairers, J. E. and Xu, N.,Temperature and Hydrologic Controls on Dissolved Organic Matter Mobilization and Transport within a Forest Topsoil. Environ. Sci. Technol.,(44), 2010, 5423-29.

[9]. Zhiming, Z.,Ex situ Conservation of Wild plants in Beijing Botanical Garden, China.Botanic Gardens Conservation News, (2), 1993, 17-21.

[10]. Tan, H. T. W., Ibrahim, P. T., Chew, K. S., Chua, H., Duistermaat, S. K., Lee, P., Leong, J. Loo, S. K. Y., Lum, T. M., Suran, S. Wee, K. F., Yap, C. K. and Yong, J. W. H., Checklists of Threatened Species-Seed Plants. In: Davison, G. W. H., Ng, P. K. L. and Ho, H. C. (eds.), The Singapore Red Data Book.2 ${ }^{\text {nd }}$ Ed.The Nature Society Singapore.Pp. 213-244, 2008.

[11]. Reaser, J. K., Meyerson, L. A., Green, E. Orapa, W., Saunders, A. and Shine, C.,Ecological and socioeconomic impacts of invasive alien species in island ecosystems. Environmental conservation, 34, 2007, 98-111.

[12]. Kokwaro, J. O. (1982). A Checklist of botanical, Samburu and Rendile names of plants of the "IPAL" study area, Marsabit District, Kenya.Published by UNESCO.

[13]. Muasya, J. M., Young, T. P. and Okebiro, D. M. (1994).Plant Checklist of Ol Ari Nyiro Ranch and the Mukutan Gorge, Laikipia Kenya. Journal of East African Natural History, (83, 1994, 143-197.

[14]. Luke, Q., Annotated Checklist of the plants of the Shimba Hill, Kwale District, Kenya. Journal of East African Natural History, 94, 2005, 5-120.

[15]. Fischer, E., Rembold, K., Althof, A., Obholzer, J., Malombe, I., Mwachala, G., Onyango, J. C., Dumbo, B. and Theisen, I. (2010). Annotated Checklist of the vascular plants of Kakamega Forest, Western Province, Kenya. Journal of East African Natural History, (99): 129-226.

[16]. Chong, K. Y., Hugh, T. W. T. and Corlett R. T. , A checklist of the total vascular plant flora of Singapore: native, naturalized and cultivated species. Raffles museum of biodiversity research, 2009.

[17]. Forzza, R. C., José, F. A., Carlos, E. M., Canhos, A. L., Sylvestre, L. S., Bruno, M. T., Zappi, D., Leitman, P. M., Lohmann, L. G., Lughadha, E. N. and Martinelli, G.,Preparation of a list of Brazilian plant and fungal species: methods and results. Proceedings of the 4th Global Botanic Gardens Congress, 2010.

[18]. Lechner, M. and Kiehn, M., Assessing invasive potentials of plant species cultivated in botanic gardens in Central Europe.Proceedings of the 4th Global Botanic Gardens Congress, June 2010.

[19]. Manha, E. M., Silva, M. C., Alves, M. G. C., Almeida, M. B. and Brandao, M. G. L. (2008). PLANT:A bibliographic database about medicinal plants. Revista Brasileira de Farmacognosia, 18, 2008, 614-617.

[20]. Heywood, V. and Brunel, S.,Code of Conduct on Horticulture and Invasive Alien Plants. Nature and Environment, 155, 2009.

[21]. Jeruto, P.,Ethno-Botanical Survey and Propagation of priority medicinal plants in Aldai region of Nandi south district. An M.Sc. Thesis, Maseno University, Kenya.

[22]. Cunningham, A. B., African-wide Overview of Medicinal Plant Harvesting Conservation and Healthcare. Non-wood forest Products 11: Medicinal Plants for Forest Conservation and Healthcare.FAO, Rome, Italy, 1997.

[23]. UNESCO,Conservation and utilization of Indigenous Medicinal plants and Wild Relatives of Food crops, UNESCO. Nairobi offices, 1997, 19-125.

[24]. Elizabetsky, E., Folklore, Tradition or know How? Cultural survival quarterly, 15, 1991, 9-13.

[25]. Kokwaro, J. O., Medicinal Plants of East Africa $\left(2^{\text {nd }} \mathrm{Ed}\right)$. (Kenya. Nairobi, East Africa Literature Bureau Publishers, 1993)

[26]. Balick, M. J. and Cox, P. A., Ethno-Botanical approach to drug discovery; Scientific American, $270,1994,82-87$.

[27]. Karori and Pulu, Foods and Herbs that Heal. Revelation Heralds, Nairobi, Kenya, 2003.

[28]. Scholes. R. J., Kuper, W. and Biggs, R.,Biodiversity (Kenya, Nairobi, Published by UNEP, 2007).

[29]. Rinker, B. H., The Weight of a Petal: The Value of Botanical Garden. Published by American Institute of Biological Sciences, 2002.

[30]. BGCI,The Global network. http://www.bgci.org/global/, accessed on 21/06/2011, 2011b

[31]. Oldfield, S., Tackling Invasive Species. BG Journal, 8, 2011, 2.

[32]. Rukangira, E.,The African Herbal Industry: Constrains and Challenges; paper presentation at the natural products and cosmeceuticalAugust 2001 conference. Erboristeria Domani, 2001. 
[33]. Govaerts, R.,World Checklist of selected plant families. Royal Botanic Gardens,Kew. http://www.Kew.org/wcsp/about.do.Accessed on 15/8/2016, 1994.

[34]. Richardson, D. M., Pysek, F. D., Rejmánek, M., Barbour, M. G., Panetta, F. D. and West, C. J. (2000). Naturalization and invasion of alienplants: concepts and definitions. Divers.Distrib. (6), 2000, 93-107.

[35]. Colautti, R. and MacIsaac, H.,A neutral terminology to define 'invasive' species. Divers. Distrib. (10), 2004, $135-141$.

[36]. Kramer, A. and Hird, A.,Building an International Sentinel Plant Network. BG Journal, 8, 2011, 3-6.

[37]. Heywood, V. and Brunel, S. (2009). Code of Conduct on Horticulture and Invasive Alien Plants. Nature and Environment, 155, Strasbourg, Council of Europe Publishing, 2011.

[38]. Reichard, S. H. and White, P., Horticultureas a pathway of invasive plantintroductions in the United States. Bioscience, 51, 2001, $1103-1113$.

[39]. Dawson, W., Mndolwa, A. S., Burslem, D. and Hulme, P.E.,Assessing therisks of plant invasions arising from collections in tropical botanical gardens. Biodiversity and Conservation, 17, 2008, 1979-1995.

[40]. Hulme, P. E., Addressing the threat to biodiversity from botanic gardens. Trends in Ecology and Evolution, 26, 2011, 168 -174

[41]. Galera, H. and Sudnik-Wójcikowsja, B.,Central European botanic gardens as centres of dispersal of alienplants. Acta Soc. Bot. Pol., 79, 2010, 147-156.

[42]. Groom, Q. J., Gall causing organisms in the National Botanic Garden of Belgium. Scripta BotanicaBelgica, 47, 2011 , $423-436$.

[43]. Facon, B., Genton, B.J., Shykoff, J., Jarne, P., Estoup, A. and David, P.,A general eco-evolutionary framework for understanding bioinvasions. Trends in Ecology and Evolution, 21, 2006, 130-135.

[44]. Sax, D. F. and Brown, J. H., The Paradox of Invasion. Global Ecology and Biogeography, 9, 2000, $363-372$.

[45]. Wikipedia Encyclopedia (2011b). http://en.wikipedia.org /wiki/invasive species. Accessed on 06/10/2011, 2011b

[46]. Keane, R. M. and Crawley, M. J., Exotic plant invasions and the enemy releasehypothesis. Trends in Ecology and Evolution, 7, 2002, 164-170.

[47]. Lozon, J. D. and MacIsaac, H. J.,Biological invasions: are they dependent on disturbance? Environ. Rev., 5, 1997, 131-144

[48]. Blossey, B. and Notzold, R., Evolution of increased competitive abilityin invasive nonindigenous plants: a hypothesis. J. Ecol., 83, $1995,887-889$

[49]. Matthiesa, D., Enßlin, A. and Sandnera, T. M.,Consequences of ex situ cultivation of plants: Genetic diversity, fitness and adaptation of the monocarpicCynoglossum officinale L.in botanic gardens.BiolConserv.144, 2011, $272-278$.

[50]. Ellstrand, N. C. and Schierenbeck, K. A., Hybridization as a stimulus forthe evolution of invasiveness in plants?Proc. Natl. Acad. Sci. U.S.A., 97, 2000, 7043-7050.

[51]. Gaskin, J. F., Wheeler, G. S., Purcell, M. F. and Taylor, G. S. (2009). Molecular evidenceof hybridization in Florida'ssheoak (Casuarina spp.) invasion. Mol. Ecol., 18, 2009, 3216-3226.

[52]. Tiébré, M-S., Vanderhoeven, S., Saad, L. and Mahy, G., Hybridization and sexual reproduction in the invasive alien Fallopia (Polygonaceae) complex in Belgium. Ann. Bot., 99, 2011, 193-203.

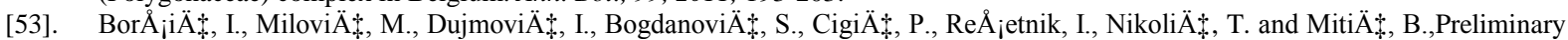
check-list of invasive alien plant species (IAS) in Croatia Natura Croatica, 17, 2008, 55-71.

[54]. Binggeli, P., Desalegn, D., Healey, J., Painton, M., Smith, J. and Teklehaimanot, Z., Conservation of Ethiopian sacred groves.ETFRN News, 38, 2003, 37-38.

[55]. Kikodze, D., Memiadze, N., Kharazishvili, D., Manvelidze, Z. and Mueller-Schaerer, H.,The Alien Flora of Georgia. Joint SNSF SCOPES and FOEN publication, 2010

[56]. Nyunja, A. R. O., Diversity of medicinal plants of Kakamega forest, Kenya: A taxonomic and pharmacological approach. A PhD. Thesis, Maseno University, Kenya, 2007.

[57]. WCMC, Global Biodiversity: Status of the Earth's Living Resources. (London, Chapman and Hall, 1992).

[58]. UNCED (1992). United Nations Conference on Environment and Development. (Rio Protocol, 1992).

[59]. Ludeki, J. V., Wamukoya, G. M. and Walubengo, Environmental Management in Kenya: A Framework for Sustainable Forest Management in Kenya-Understanding the Forest Policy and Forests Act (2005), 2006.

[60]. BGCI, African Botanic Gardens Network. http://www.bgci.org/africa/abgn, accessed on 09/07/2011, 2011d.

[61]. [62]Cunningham, A. B. (1990). African Medicinal Plants. Setting priorities at the interface between Conservation and Health.WWF 3331 Report, plants conservation section, WWF International, 1990.

[62]. Arwa, S. P., Ethno-Botanical Survey and Palynological characterization of some medicinal plants in Kombewa division of Kisumu district.An M.Sc. thesis,Maseno University, Kenya, 2005.

[63]. Spellerberg, I. F. and Hardes, S. (1992). Biological Conservation(Cambridge, Cambridge University Press, 1992).

[64]. Primack, R. B. and Miller, A. J. R., Role of botanical garden in climate change research. NewPhytol. 182, 2009, 303-313.

[65]. BGEN,Supporting inspirational learning about plants and their importance. http//www.bgen.org.uk/. Accessed on 19/08/2011, 2010 .

[66]. Shiwei, Z and Zuoshuang, Z.,The Management of Living Collections in Beijing Botanical Garden (North).BGjournal, 3, 2006.

[67]. BERC, Til Botanic Gardens, Education at BERC-Til Botanic gardens, Palestine, 2003.

[68]. Garrod, G., Pickering,A. and Willis, K., The economic value of botanic gardens: a recreational perspective. Geoforum,24, 1993, 215-224.

[69]. Toby, S.,The Aesthetic and Economic Value of Aztec Gardens (Ch., 5).Botanical Progress, Horticultural Innovations, and Cultural Changes, (Ed.).(Michel Conan Washington DC: Dumbarton Oaks, 2007), 81-101.

[70]. Noad, T. and Birnie, A., Trees of Kenya (Kenya, Nairobi, General printers Ltd, 1992).

[71]. Agnew, A. D. Q and Agnew, S., Upland Kenya Wild Flowers. A Flora of the Ferns and Herbaceous Flowering Plants of Upland Kenya $\left(2^{\text {nd }}\right.$ Edition) (Kenya, Nairobi: East African Natural History, 1994).

[72]. Olembo,N.K, Fedha, S.S. and Ngaira, S.E., Medicinal and Agricultural Plants of Ikolomani Division Kakamega district. (Kenya, Nairobi: Signal press Ltd, 1995).

[73]. Kokwaro, J. O.,Flowering Plant Families of East Africa. An Introduction to PlantTaxonomy (Kenya, Nairobi: East African Educational Publishers, 1994)

[74]. Kothari, C. R.,Quantitative Techniques (3 ${ }^{\text {rd }}$ Edition). (India, New Delhi: Vikas Publishing House PVT Ltd, 2008).

[75]. Stace, A. C., Taxonomy and Biosystematics $\left(2^{\text {nd }}\right.$ Ed). (London: Oxford University Press, 1993).

[76]. Okello, S. V., Ethno-botanical survey and phytochemical analysis of medicinal plants in Kopsiro division of Mt. Elgon district, Kenya. An M.Sc. thesis, Maseno University, Kenya, 2007.

[77]. Brummitt, R. K. and Powell, C. E., Authors of plant names (Kew, Royal Botanic Garden., 1992).

[78]. Kokwaro, J. O., Medicinal Plants of East Africa. (Kenya, Nairobi: East Africa Literature Bureau Publishers, 1976).

[79]. Duke, A. J., Handbook of Edible Weeds (U.S.A.: CRC press, 1992) 
[80]. Maundu, M. P., Traditional Food Plants of Kenya. Published by Kenya Resource Centre for Indigenous Knowledge (KENRIK). (Kenya, Nairobi: National Museums of Kenya, 1999).

[81]. Armstrong, W. P.,Hardwoods Trees\& Shrubs with dense, hard wood.http://waynesword.palomar.edu/plsept99.htm.. Accessed on 24/7,2016.

[82]. Mendonça, M. P., Windham-Bellord, K. A., Andrade, D. C. and Veríssimo, M. P., Economic Valuation of the Botanic Garden ofthe Zoo-Botanic Foundation Belo Horizonte, Minas Gerais.BGCI, 2011.

[83]. Seth, M. K.,Trees and their Economic Importance. The Botanical Review, 69, 2004, 321-376.

[84]. Wildlife Direct, Perfumerysends Sandalwood number down (Kenya, Nairobi: Published by Kenya Forest Research Institute, 2009)

[85]. Maundu, P. and Tengnas, B., Useful Trees and Shrubs for Kenya Technical: Handbook No. 35. (Kenya, Nairobi: World AgroForestry Centre, Eastern and Central Africa Regional Programme, 2005).

[86]. Lwande, G., A leading Provincial Rural Health Demonstration and Medical Centre Providing Quality Service Delivery: Climate and Social Economic Factors.http://www.chulaimbohospital.or.ke/.Accessed on 30/6/2012, 2008)

[87]. Clubbe, C., Hamilton, M. and Corcoran, M., The role of native species nurseries in mitigating threats from invasive species: case studies from UK Overseas Territory. Proceedings of the 4th Global Botanic Gardens Congress, 2010.

[88]. Biodiversity database programe,Ohio Invasive Non-nativePlantshttp://ohiodnr.com/tabid/2007, accessed on 26/6/2012, 2007.

[89]. Lapin, B., Marks, M. and Randall, J., Phragmites australis (P. communis): Threats, Management and Monitoring. Natural Areas Journal, 14, 1994, 285-294

[90]. Taiwan Invasive Species Database, www.eFlora.org.Accessed on 4/6/2012, 2011

[91]. Hagne, M., Native Lantana Species of the Lower Rio Grande Valley. The Sabal, 26, 2009, 3

[92]. Florida Exotic Pest Plant Council,"Florida Exotic Pest Plant Council: Lantana camara"http://www.fleppc.org/ID f.Accessed on book/lantana/20camara.pdf. Accessed on the 2015, 2005.

[93]. New South Wales National Parks and Wildlife Service, Lantana - fact sheet. Department of Environment and Climate Change NSW http://www.nationalparks.nsw.gov.au/npws.nsf/content/lantanafactsheet, accessed 29/6/2012, 2007

[94]. Sathisha, R., Vyawaharea, B. and Natarajanb, K.,Antiulcerogenic activity of Lantana camara leaves on gastric and duodenal ulcers in experimental rats.Journal of Ethnopharmacology, 134, 2011, 195-197.

[95]. Barreto, F., Sousa, E., Campos, A., Costa, J. and Rodrigues, F., Antibacterial activity of Lantana camara Linn and Lantana montevidensis Brig Extracts from Cariri-Ceará, Brazil. J. Young Pharm., 2, 2010, 42-44.

[96]. ISSG database (2012). Lantana camara. http://www.issg.org/database/species/ecology. Accessed 30 ${ }^{\text {th }}$ April 2012, 2012

[97]. Ankila, H. and Sundram, B., The Fire-Lantana Cycle Hypothesis in Indian Forests. Conservation and Society.

[98]. http://dlc.dlib.indiana.edu/archive/00002445/.Accessed on 18/5/2012, 2005.

[99]. Hall, C. R. and Dickson, M. W.,Economic, Environmental, and Health/Well-Being Benefits Associated with Green Industry Products and Services: A Review 1. Journal of Environ. Hort., (29, 2011, 96-103. 